\title{
A Review of Known and Hypothetical Transmission Routes for Noroviruses
}

\author{
Elisabeth Mathijs $\cdot$ Ambroos Stals $\cdot$ Leen Baert $\cdot$ Nadine Botteldoorn $\cdot$ Sarah Denayer \\ Axel Mauroy • Alexandra Scipioni · Georges Daube - Katelijne Dierick • Lieve Herman • \\ Els Van Coillie $\cdot$ Mieke Uyttendaele $\cdot$ Etienne Thiry
}

Received: 21 February 2012/ Accepted: 6 October 2012/Published online: 3 November 2012

(C) Springer Science+Business Media New York 2012

\begin{abstract}
Human noroviruses (NoVs) are considered a worldwide leading cause of acute non-bacterial gastroenteritis. Due to a combination of prolonged shedding of high virus levels in feces, virus particle shedding during asymptomatic infections, and a high environmental persistence, NoVs are easily transmitted pathogens. Norovirus (NoV) outbreaks have often been reported and tend to affect a lot of people. NoV is spread via feces and vomit, but this NoV spread can occur through several transmission routes. While person-to-person transmission is without a doubt the dominant transmission route, human infective
\end{abstract}

Elisabeth Mathijs and Ambroos Stals contributed equally to this work.

E. Mathijs · A. Mauroy $\cdot$ A. Scipioni $\cdot$ E. Thiry

Department of Infectious and Parasitic diseases, Virology and Viral diseases, Faculty of Veterinary Medicine, University of Liège, Boulevard du Colonster 20, 4000 Liège, Belgium

E. Mathijs · G. Daube

Food Science Department, Food Microbiology, Faculty of Veterinary Medicine, University of Liège, Boulevard du Colonster 20, 4000 Liège, Belgium

A. Stals $(\varangle) \cdot$ L. Baert $\cdot$ M. Uyttendaele

Laboratory of Food Microbiology and Food Preservation,

Department of Food Safety and Food Quality, Faculty

of Bioscience Engineering, Ghent University, Coupure Links

653, 9000 Ghent, Belgium

e-mail: Ambroos.stals@ilvo.vlaanderen.be

A. Stals - L. Herman - E. Van Coillie

Technology and Food Science Unit, Institute for Agricultural and Fisheries Research (ILVO), Brusselsesteenweg 370, 9090

Melle, Belgium

N. Botteldoorn · S. Denayer · K. Dierick

Division of Bacteriology, Department of Microbiology, Belgian Scientific Institute of Public Health, Juliette Wytsmanstraat 14, 1050 Brussels, Belgium
NoV outbreaks are often initiated by contaminated food or water. Zoonotic transmission of NoV has been investigated, but has thus far not been demonstrated. The presented review aims to give an overview of these $\mathrm{NoV}$ transmission routes. Regarding NoV person-to-person transmission, the NoV GII.4 genotype is discussed in the current review as it has been very successful for several decades but reasons for its success have only recently been suggested. Both pre-harvest and post-harvest contamination of food products can lead to NoV food borne illness. Pre-harvest contamination of food products mainly occurs via contact with polluted irrigation water in case of fresh produce or with contaminated harvesting water in case of bivalve molluscan shellfish. On the other hand, an infected food handler is considered as a major cause of post-harvest contamination of food products. Both transmission routes are reviewed by a summary of described NoV food borne outbreaks between 2000 and 2010. A third NoV transmission route occurs via water and the spread of NoV via river water, ground water, and surface water is reviewed. Finally, although zoonotic transmission remains hypothetical, a summary on the bovine and porcine NoV presence observed in animals is given and the presence of human infective NoV in animals is discussed.

Keywords Norovirus - Transmission route $\cdot$ Person-toperson $\cdot$ Food $\cdot$ Water $\cdot$ Zoonotic

\section{Introduction}

Noroviruses (NoVs) were discovered in 1972 by immune electron microscopy analysis of fecal samples of volunteers challenged with fecal filtrates from a group of elementary school students affected by an outbreak of gastroenteritis in 
1968 in Norwalk, Ohio (Kapikian et al. 1972). The 27-32 nm viral agent was originally named Norwalk virus and was later recognized as the type agent of the genus Norovirus (previously denoted as "Norwalk-like viruses" or "small round structured viruses"). Similar to human infective NoVs, animal infective NoVs were discovered by electron microscopy of stool samples of domestic animal species (calves and pigs) suffering from gastroenteritis (Bridger 1980; Saif et al. 1980; Woode and Bridger 1978).

Together with the genera Sapovirus (previously called "Sapporo-like viruses"), Lagovirus, Vesivirus, and Nebovirus, the Norovirus genus forms the Caliciviridae family (Green et al. 2000). The Norovirus genus comprises five genogroups (GI to GV) each containing several NoV genotypes (Zheng et al. 2006). Genogroups I and II (GI and GII) consist of 8 and 17-extended to 19 by Wang et al. (2007)_NoV genotypes, respectively. These genogroups comprise the human infective NoV genotypes, together with the Alphatron and Ft. Lauerdale genotypes in genogroup IV (GIV). The latter genogroup also contains a number of NoV genotypes infecting carnivores such as dogs, lions, and cats (Martella et al. 2007; Martella et al. 2008; Pinto et al. 2012). Bovine and murine NoV are classified in genogroup III (GIII) and V (GV), respectively, while porcine $\mathrm{NoV}$ is also classified in GII. Human infective NoVs are among the most important causes of gastroenteritis in adults worldwide and NoV infections often occur as outbreaks (Koopmans and Duizer 2004). On the other hand, the true extent of the host range of animal NoVs remains unknown although it is known that a large number of animal species can be infected with NoVs (Scipioni et al. 2008).

Human and animal infective NoVs are spread via feces and vomit through different transmission routes. Due to the development of sensitive methods for molecular detection of NoVs, knowledge on these NoV transmission routes has increased substantially. The current review, therefore, aimed to provide an overview of known transmission routes, specifically of human infective NoVs. Furthermore, the presence of animal infective NoVs in bovine and porcine animals and the possibility of zoonotic transmission of NoVs were discussed.

\section{Transmission Routes of NoV}

Described transmission routes of human infective NoVs include person-to-person transmission (chapter 3.1), food borne transmission (chapter 3.2), and water borne transmission (chapter 3.3) while zoonotic transmission (chapter 3.4) has been considered a hypothetical-yet unprovedroute for NoV transmission.
A schematic overview of proven and hypothetical transmission routes for human and animal infective NoVs is shown in Fig. 1. Transmission of human infective NoVs is facilitated by a number of factors such as (i) prolonged duration of viral shedding, even after resolving of the symptoms (Aoki et al. 2010; Atmar et al. 2008; Lee et al. 2007), (ii) fecal shedding during asymptomatic NoV infections (Gallimore et al. 2004b; Ozawa et al. 2007; Phillips et al. 2010), and (iii) NoV persistence on environmental surfaces and in water and foods (Escudero et al. 2012; Lamhoujeb et al. 2009; Liu et al. 2009b; Ueki et al. 2007).

\section{Person-to-Person Transmission}

Although human infective NoVs can be transmitted through several routes, person-to-person transmission is considered to be the dominant $\mathrm{NoV}$ transmission route (Fig. 1) (Kroneman et al. 2008). NoV outbreaks related to this transmission route have extensively been documented in semi-closed community settings such as hospitals, cruise ships, day-care centers, and military settings and can affect a few to a lot of people (Gallimore et al. 2004a, b; Grotto et al. 2004; Takkinen 2006; Wick 2012). Recently, NoV outbreaks between 2002 and 2006 were investigated using data collected by 11 surveillance systems of the Food borne Viruses in Europe (FBVE) network (Verhoef et al. 2010). Out of 886 confirmed norovirus outbreaks with known transmission route, 654 outbreaks $(74 \%)$ involved personto-person contamination. Similarly, Lopman et al. (2003) and Siebenga et al. (2007) found that person-to-person spread was the transmission route in $85 \%$ and $82 \%$ of NoV outbreaks with a known mode of transmission in the UK and in The Netherlands, respectively.

The NoV genotype most commonly identified in personto-person NoV gastroenteritis outbreaks is the NoV GII.4 genotype (Kroneman et al. 2008; Verhoef et al. 2010, 2009). Therefore, its epochal evolution has been documented thoroughly between 1974 and 2007. In the USA, only 2 major NoV GII.4 strains were observed between 1974 and 1994 (a NoV GII.4 ancestor strain and GII.4 Camberwell). In the 7 year period between 1995 and 2002 a single major NoV GII.4 strain was considered dominant (NoV GII.4 Grimsby) both in Europe and in the USA. Subsequently, NoV GII.4 Farmington Hills and Hunter (also named NoV GII.4 2002 and NoV GII.4 2004, respectively, in Europe) caused $2 \mathrm{NoV}$ epidemic seasons in 2002-2003 and 2004-2005. Finally, NoV GII.4 Laurens and NoV GII.4 Den Haag (also named GII.4 2006a and GII.4 2006b in Europe) have caused NoV epidemics since 2006 (Bok et al. 2009; Siebenga et al. 2009; Zheng et al. 2009). Bull and White (2011) recently reviewed reasons for the success of the NoV GII.4 genotype and they concluded 
Fig. 1 Schematic overview of the transmission routes of human and animal infective NoVs. Solid and dashed arrows indicate proven and hypothetical transmission routes, respectively. The thickness of the arrows is related to the likeliness of the transmission route

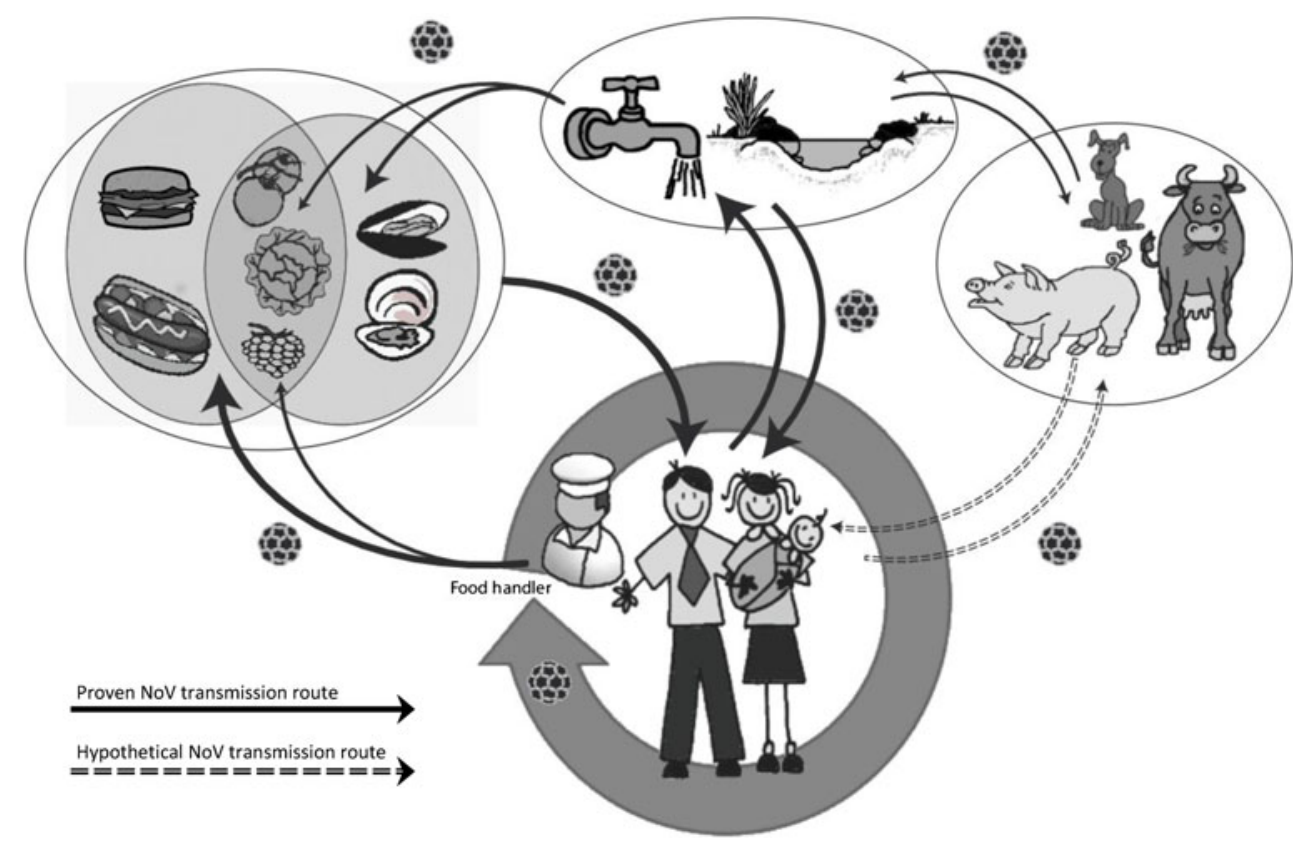

that a synergism of multiple factors could be responsible for its success. First of all, NoV GII.4 has a mutation rate that is approximately 2-fold higher compared to other NoV genotypes (Bok et al. 2009; Bull et al. 2010; Siebenga et al. 2010). This could in part be caused by the NoV GII.4 RNA dependent RNA polymerase which has shown a lower fidelity compared to some other NoV genotypes, enabling the more prevalent viruses to avoid immune recognition by rapidly altering their antigenic properties (Bull et al. 2010; Bull and White 2011). Second, NoV GII.4 can bind more histo-blood group antigen (HBGA) types than any other NoV genotype, which could be a major contributing factor to the NoV GII.4 dominance (Bull and White 2011). Third, while long-term immunity may be possible for some $\mathrm{NoV}$ genotypes (e.g., GII.3), it is possible that this is not the case for GII.4 NoV (Bull and White 2011; Siebenga et al. 2009; Yang et al. 2010). However, only limited research has been performed on each factor and further study is needed.

\section{Food Borne Transmission}

Person-to-person transmission is without a doubt the dominant transmission route for $\mathrm{NoV}$, but the primary cases in NoV outbreaks often have a food or water borne cause (Fig. 1). Person-to-person transmission among contacts of primary cases can further propagate the epidemic (Becker et al. 2000; Patel et al. 2009). Food products can be contaminated with NoV by contact with fecal material or vomit, which can occur during any stage of the food production (Baert et al. 2011). In essence, NoV contamination of foods can occur during at a pre-harvest level, e.g., by irrigation of fresh produce with NoV contaminated water or by use of contaminated manure, or at a (post-) harvest level, e.g., by manual picking, processing, and preparation of foods such as strawberries and raspberries (Wei and Kniel 2010; Zainazor et al. 2010).

The current paragraph will go more into detail regarding these transmission routes by a literature review of studies investigating individual NoV food borne outbreaks. In total, 51 studies describing 58 outbreaks that occurred between 2000 and 2010 were reviewed (Table 1). The number of described NoV food borne outbreaks is considered as a serious underestimation of the actual number and is probably biased because peer-reviewed publications of food borne outbreaks merely report large, welldocumented, unusual, or novel events (Baert et al. 2009b; Kroneman et al. 2008; O'Brien et al. 2006). Furthermore, NoV illness is normally self-limiting and complications are not common which could lead to a further underestimation of NoV food borne gastroenteritis outbreaks (Greening 2006; Lopman et al. 2002).

A food borne outbreak has been defined by multiple official authorities such as the European Food Safety Authority (EFSA), the World Health Organization (WHO), and the Centers for Disease Control and Prevention (CDC). However, all definitions include the occurrence of two or more human cases of a same/similar disease resulting from the same food source(s) (Anonymous 2000, 2010; World Health Organization 2008). All reviewed outbreaks complied with these definitions and the NoV food borne outbreak data were categorized in Table 1 per transmission route: by pre-harvest contamination or by (post-) harvest contamination. Regarding the latter transmission route, focus was set on infected food handlers, either confirmed or 


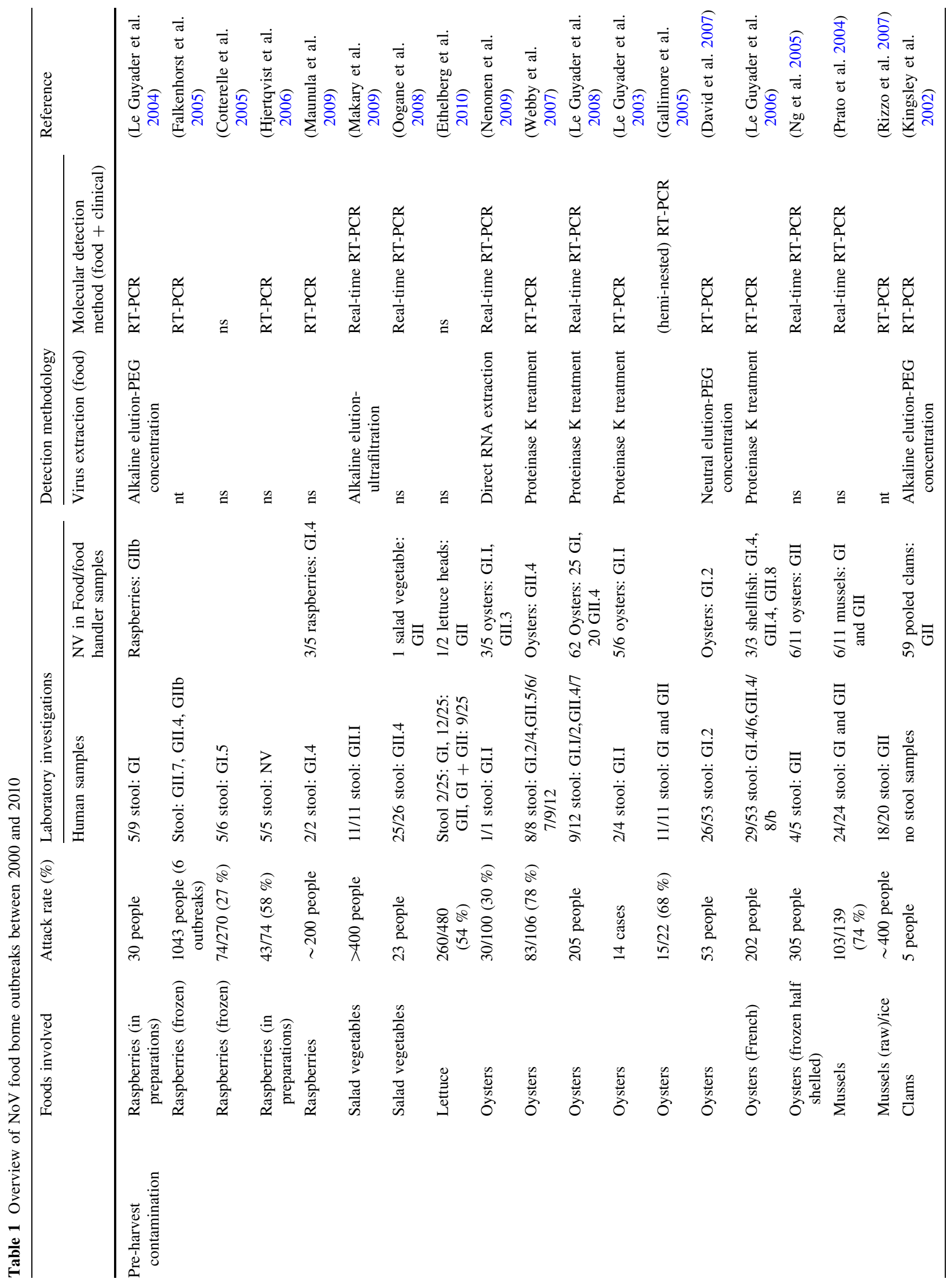




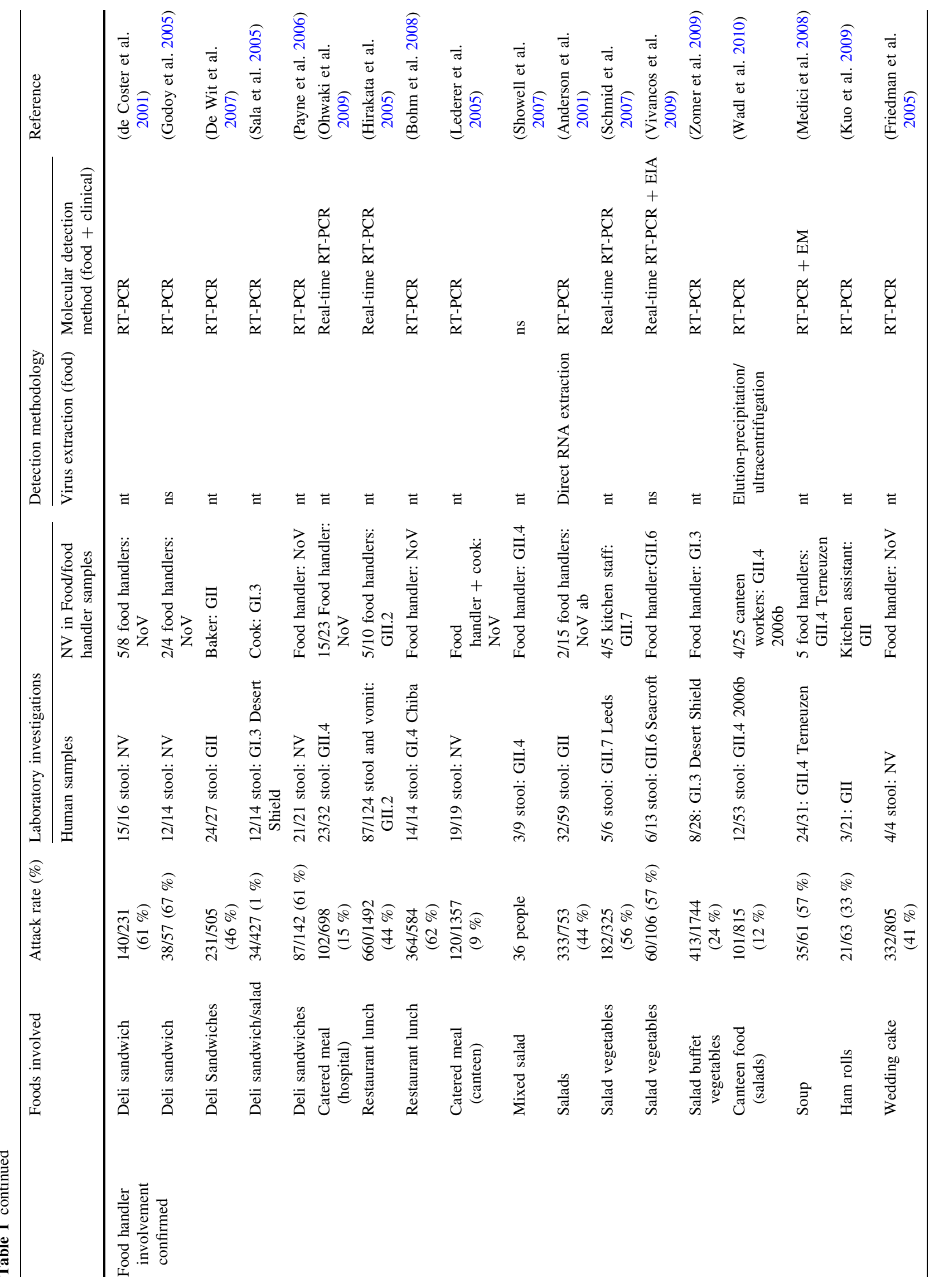




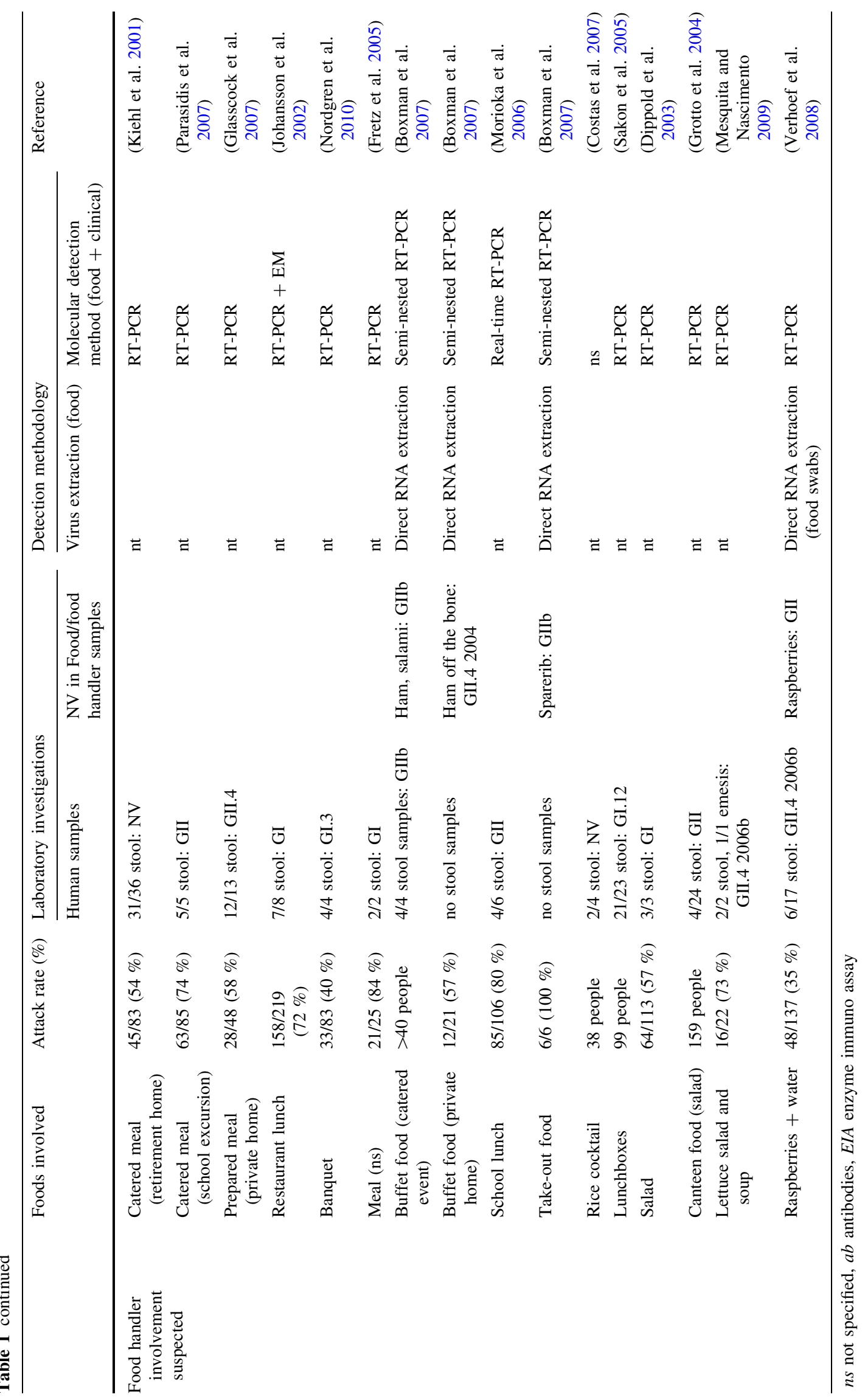


suspected (Table 1). The involvement of a NoV infected food handler in a NoV food borne outbreak was considered confirmed if (i) epidemiological analysis showed that the food handler was infected before the food borne outbreak and could be linked to manipulation of the involved food products and if (ii) laboratory analysis showed identical NoV genogroups or genotypes in the clinical samples from both patients and food handler. For every reviewed NoV food borne outbreak in Table 1 , the attack rate (the number of exposed individuals infected with NoV divided by the number of exposed individuals in a NoV food borne outbreak), and/or the number of affected people and the laboratory confirmation of the NoV presence in human and/or food samples were described. Regardless of the transmission route, some trends were clearly noticeable. Overall, RT-PCR was the most used NoV detection method as it was used in 47 of 51 (92\%) studies. Extraction of virus particles or viral genomic material from the food samples was performed by various methods. Of the 23 studies (45\%) that tested the NoV presence on food products, 14 studies $(61 \%)$ used elution-concentration extraction, proteinase $\mathrm{K}$ treatment, and direct RNA extraction to extract NoV from food, while 9 (39\%) studies did not specify the used virus extraction method (Table 1). In general, all but two studies (Boxman et al. 2007; Kingsley et al. 2002) combined epidemiological investigations with molecular detection of NoVs in clinical samples. A smaller fraction of studies $(29 \%)$ was able to demonstrate the NoV presence in the suspected food products (Table 1).

\section{Pre-Harvest Contamination of Food Products}

In general, food products most at risk for pre-harvest NoV contamination include fresh produce and shellfish (Baert et al. 2011; Lowther et al. 2012; Mattison et al. 2010; Stals et al. 2011b). NoV contamination of fresh produce at a preharvest stage can result from contact with polluted irrigation water or contaminated manure (Wei and Kniel 2010), while shellfish can be contaminated if grown in $\mathrm{NoV}$ contaminated harvesting areas (Lowther et al. 2008). Table 1 showed that 24 out of $58(41.4 \%)$ NoV food borne outbreaks could be related to consumption of pre-harvest contaminated fresh produce and shellfish and that mainly raspberries and oysters were involved in these outbreaks. An average attack rate of $51 \%$ was observed with an average of 145 people exposed per outbreak. The most observed NoV genotype in clinical and food samples was GII.4, although NoV genotypes GI.1, GI.2, GI.4, and GII.7 were frequently detected in food and clinical samples as well.

In $42 \%$ (10 out of 24) of these outbreaks, identical genogroups or genotypes were found in clinical and food samples. In an additional $8 \%$ (2 out of 24) of these NoV food borne outbreaks, different NoV genotypes were detected in clinical and food samples. Noteworthy, NoV could be detected in shellfish samples in 9 of $11(82 \%)$ studies, which could be explained by the higher levels of NoV found in shellfish compared to other food products due to their filter feeding capacity (Meyers 1984).

NoV and other viral pathogens have been observed in shellfish by several screening studies. A 3 year survey between 2005 and 2008 investigating 116 retail shellfish samples (mussels, clams, and oysters) showed a confirmed (sequenced) detection of NoV genotypes GII.4 2004 and GIIb in $10.3 \%$ of all tested samples (Terio et al. 2010). Likewise, GII.4 and GIIb genotypes were found in $16.7 \%$ of oyster and mussel samples $(n=42)$ during a 2 year survey for the NoV presence in Dutch shellfish (Boxman et al. 2006) while a 1 year survey in 235 Italian shellfish samples showed the presence of NoV and HAV in $13.2 \%$ and $2.2 \%$ of all tested samples, respectively (Croci et al. 2007). Although some studies found NoV GII.4 in shellfish samples related to NoV food borne outbreaks, the GIIb genotype was not encountered in any of these studies (Table 1). A lower NoV presence was observed when 1512 Japanese oysters were screened for the NoV presence as a broad range of GI and GII NoV genotypes were found in $4.9 \%$ of all tested oyster samples (Nishida et al. 2007). NoV have been detected in sewage with high concentrations (339 to $10^{6} \mathrm{NoV}$ genomic copies per liter) and treatment of the sewage caused only a minor reduction of 0.7-2.7 logs NoV genomic copies per liter (Lodder and de Roda Husman 2005; van den Berg et al. 2005). A Japanese study has shown that very similar NoV genotypes can be detected in human feces, domestic sewage, treated wastewater, river water, and in cultivated oysters (Ueki et al. 2005), demonstrating that transmission of NoV from contaminated harvesting water to bivalve filter feeding shellfish such as mussels or oysters is possible. Although numerous studies using PCR have demonstrated the NoV presence in various shellfish and shellfish harvesting areas, the number of epidemiologically confirmed shellfish-associated outbreaks is relatively low. Lowther et al. (2012) found that the number of genomic copies detected in shellfish samples was significantly higher in outbreak related samples (mean level of 2148 NoV genomic copies/ g) compared to non-outbreak related samples (mean level of $682 \mathrm{NoV}$ genomic copies/g). Although more data is needed, a critical level may aid NoV risk management in shellfish. As critical limits of 100, 200, 500, 1000, or $10.000 \mathrm{NoV}$ genomic copies would result in the rejection of 33.6 to $88.9,24.4$ to $83.3,10.0$ to $72.2,7.7$ to 44.4 , or 0 to $11.1 \%$ of batches, respectively (Anonymous 2012), careful consideration of a possible NoV critical limit in oysters and other shellfish is needed. 
Regarding the NoV food borne outbreaks related to consumption of pre-harvest contaminated raspberries, two out of five studies were able to recover NoV from this food matrix (Le Guyader et al. 2004; Maunula et al. 2009). Multiple authors have stated that detection of NoVs in raspberries can be challenging, especially if the NoV levels are lower than $10^{4}$ genomic copies per 10-15 g (Stals et al. 2011c; Summa et al. 2012a). However, as a quantitative method was not applied in both outbreak studies, the NoV levels on the raspberries could not be determined. Only a limited number of studies have investigated the pre-harvest presence of enteric viruses on fresh produce. NoV and adenovirus have been detected in a single spinach sample when screening 30 produce samples for the enteric virus presence (Cheong et al. 2009). A recent review by Baert et al. (2011) summarized a Belgian, a Canadian, and a French study screening the NoV presence on fresh produce (Mattison et al. 2010; Stals et al. 2011b). NoV was detected by real-time RT-PCR in $28 \%(n=641), 33 \%(n=6)$, and $50 \%(n=6)$ of leafy greens tested in Canada, Belgium, and France, respectively. Soft red fruits were found positive in $35 \%(n=29)$ and $7 \%(n=150)$ of the samples tested in Belgium and France, respectively. However, subsequent sequencing of a conventional RTPCR amplicon was successful in merely $7 \%$ of all positive results. The latter finding gave rise to questions regarding the interpretation of NoV-positive real-time RT-PCR results in the light of the increase in sensitivity of the NoV detection methodology. The authors suggested that strategies to confirm the results by real-time RT-PCR should be developed in analogy with the detection of microbial pathogens in foods (Baert et al. 2011). Although a critical limit for food products such as raspberries and other fresh produce-similar to shellfish-is an option for risk management, further research is needed regarding a potential link between NoV levels on fresh produce and related food borne illness.

\section{(Post-) Harvest Contamination of Food Products}

Contamination of food products at post-harvest stage can occur at any point during harvesting, processing, preparing, and packing of the food (Moe 2008; Todd et al. 2009). The current review focussed on the transmission of NoV by infected food handlers, as they have been confirmed to play a major role in NoV transmission (Baert et al. 2009b; Widdowson et al. 2005b). Table 1 showed that food handlers were involved in 34 out of $58(58 \%)$ NoV food borne outbreaks, either suspected (16 out of 34 outbreaks) or confirmed (18 out of 34 outbreaks). Deli sandwiches were the most frequent implicated foods in these food borne outbreaks, but as expected, a wide range of food products including catered meals, buffet foods, and prepared salads have been involved. An average attack rate of $34 \%$ was observed with 120 people averagely exposed per outbreak, which was comparable to the NoV food borne outbreaks caused by pre-harvest contaminated foods. Remarkably, NoV could be detected in food samples in merely $12 \%$ (4 out of 34) of studies investigating $\mathrm{NoV}$ food borne outbreaks related to infected food handlers, while this was possible in $50 \%$ (12 out of 24) of food samples in studies investigating NoV food borne outbreaks related to preharvest contamination of foods. This difference can be explained by the fact that NoV detection in ready-to-eat foods such as catered foods and deli sandwiches is substantially more difficult compared to fresh produce and shellfish (Stals et al. 2011a, c). The main reason for this is the composition of the food products; while fresh produce is largely composed of carbohydrates and water, ready-toeat foods contain a lot of fat and proteins (Baert et al. 2008). As expected, the most frequently detected NoV genotype in clinical samples was the GII.4 genotype, although NoV GI.3 was detected in some outbreaks as well (Table 2).

The role of the food handler is considered an important factor for food borne transmission of NoVs due to several factors. First of all, it has been stated that an apparent NoV infection of a food handler should always be reported to avoid NoV food borne outbreaks and that an infected food handler should not be at a work place where foods are manipulated (Joint FAO/WHO Codex Alimentarius Commission and Joint FAO/WHO Food Standards Program 2003; Moe 2008; Vivancos et al. 2009). Since food handlers are often related to large catering establishments, outbreaks related to this transmission route tend to affect a lot of people at once (Noda et al. 2008). However, food handlers returning to work after recovering from a NoV infection can still shed considerable NoV levels and can cause NoV food borne outbreaks (Atmar et al. 2008; Malek et al. 2009). Second, food handlers carrying an asymptomatic NoV infection can easily cause food borne outbreaks since they can shed similarly high NoV levels (Ozawa et al. 2007; Phillips et al. 2010). Asymptomatic NoV infected food handlers manipulating deli sandwiches, prepared meals, and salad vegetables have caused NoV food borne outbreaks (Godoy et al. 2005; Ohwaki et al. 2009; Vivancos et al. 2009). Third, poor personal hygiene has been reported as well (Rizzo et al. 2007; Schmid et al. 2007), often in combination with food handlers suffering from NoV illness still coming to work (Grotto et al. 2004). Fourth, lack of respect to hygienic working circumstances can contribute to NoV food borne outbreaks (Friedman et al. 2005; Schmid et al. 2007). For example, sinks used for both washing hands and washing lettuce have been related to a NoV food borne outbreak (Payne et al. 2006). Another study reported vomiting of an ill baker in a sink in 


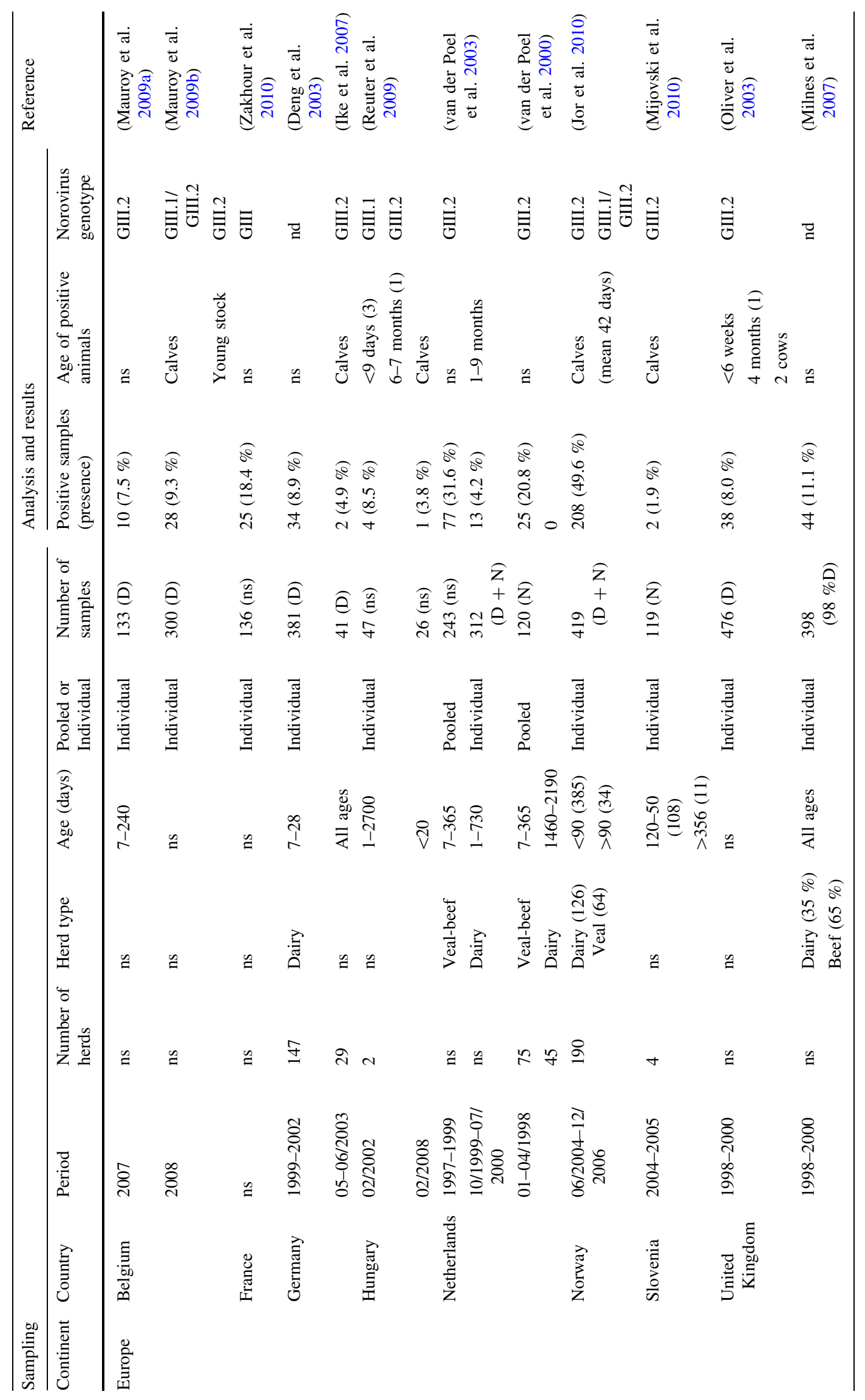




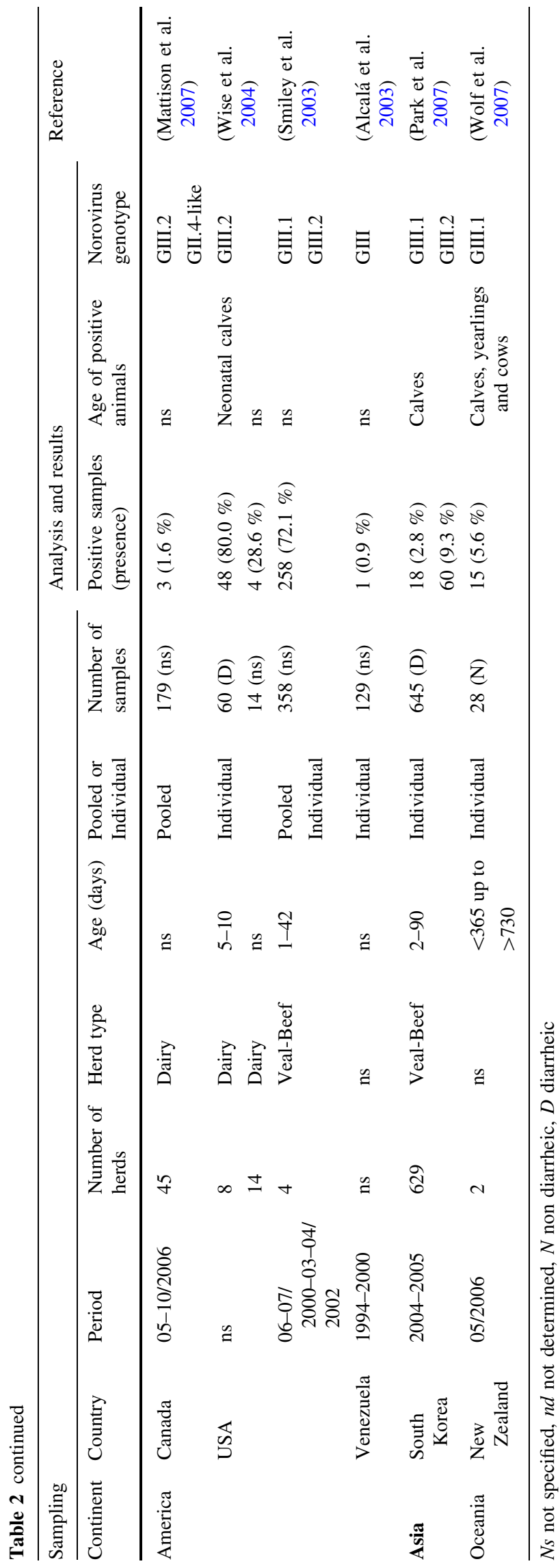

the food preparation area which resulted in NoV contamination of deli sandwiches (De Wit et al. 2007). Finally, an underestimated factor may be the presence of ill children and other family members in the food handler's home environment. Nevertheless, a few studies have mentioned this as a risk factor for NoV food borne outbreaks (Boxman et al. 2007; Daniels et al. 2000).

Food Borne Norovirus Outbreaks in Belgium (2004-2009)

As the current review has been a cooperation between different Belgian laboratories, we were able to review Belgian NoV food borne outbreaks more into detail with regards to the possible NoV transmission routes. In Belgium, a convention between the Flemish Community and the National Reference Laboratory for Food borne Outbreaks (NRLFBO) allowed analysis by the latter laboratory of human samples in suspected NoV food borne outbreaks.

In Belgium, it has been observed that in $20-50 \%$ of the reported food borne outbreaks the causative agent remains unknown and it is suspected that NoV could be partially responsible for these unknown cases. Reasons for this include a low reporting rate as NoV illness is normally self-limiting and complications are rare (Greening 2006; Lopman et al. 2002). Furthermore, analysis of clinical samples of patients is not reimbursed in Belgium. A NoV extraction and detection protocol as described by Baert et al. (2008) and Stals et al. (2011a) was introduced in the NRL-FBO in 2006. While only six NoV food borne outbreaks were altogether observed in 2004, 2005, and 2006, this number increased in 2007 to ten while seven $\mathrm{NoV}$ food borne outbreaks were reported in 2008 and in 2009.

In 2006, two subsequent NoV food borne outbreaks in a care center for disabled persons were investigated. During the first episode, 12 persons became ill and NoV GII was found in a "witness meal," a food sample that is explicitly stored for a certain time (usually $72 \mathrm{~h}$ to 1 week at $4{ }^{\circ} \mathrm{C}$ or at $-20{ }^{\circ} \mathrm{C}$ ) to allow analysis of the food in case of a food borne outbreak. Four months later, 50 people became ill in the same institute and a mixture of NoV GI and GII was found in one of the witness meals analyzed. These subsequent outbreaks are an example of recurring NoV outbreaks in health care facilities such as nursing homes and hospitals (Cieslak et al. 2009; Koopmans 2009; Rosenthal et al. 2011). A third outbreak took place in a hospital where 17 out of 400 people became ill. NoV GII was detected in the soup and also in five out of six fecal samples and epidemiological data indicated that an infected food handler distributing the soup could have been at the origin of this infection. Although soup is not commonly associated with NoV outbreaks, it has been pointed out as a vehicle for NoV transmission in a NoV outbreak in a residentialcare facility for the elderly (Medici et al. 2008). 
In ten out of the 75 food borne outbreaks reported to the NRL-FBO during 2007, NoV was confirmed as causative agent and in total 392 persons were affected. The majority of outbreaks occurred at work (30\%), camp sites $(20 \%)$, and nursing homes $(20 \%)$, and the involvement of a food handler was suspected in eight outbreaks. Noteworthy, the NoV presence could be shown in food samples in five out of ten $(50 \%)$ NoV food borne outbreaks demonstrating the effectiveness of the NoV detection method described by Baert et al. (2008) and Stals et al. (2011a) on naturally NoV contaminated food samples such as soup, chicken and rice, mashed potatoes, meat stew, and a composite meal. The most important vehicles for NoV transmission were deli sandwiches as they were involved in four out of ten $\mathrm{NoV}$ food borne outbreaks.

NoV caused seven food borne outbreaks in 2008. In two outbreaks, deli sandwiches were indicated as vehicles for NoV transmission. While only fecal samples showed the NoV presence in a first outbreak affecting 200 people, three deli sandwich fillings (meatball, cheese, and chicken curry) and food handler's fecal sample were found NoV positive in a second outbreak affecting 15 people. A third outbreak resulted in NoV illness of 80 people participating at different barbecues. Fecal samples from ill persons in the latter outbreak tested positive for the NoV presence, but NoV could not be found in the food. Interestingly, in the food handler's family there was a history of gastroenteritis a week before the barbecues took place, which confirms the importance of NoV infections in the food handler's environment (Boxman et al. 2007; Daniels et al. 2000).

Finally, in five out of seven NoV food borne outbreaks in 2009, the NoV presence could only be confirmed in fecal samples of patients and/or of food handlers. In two out of seven outbreaks, foods were confirmed as vehicle for NoV transmission.

The NoV food borne outbreaks in Belgium confirm trends that have been observed worldwide. Most importantly, the majority of NoV food borne outbreaks were related to infected food handlers, which confirms their important role in NoV transmission (Moe 2008).

\section{Water Borne Transmission}

Transmission of NoV via water can occur by several routes, although initial contamination is always caused by discharge of human fecal material (Bosch 1998). NoVs and NoV surrogate viruses can efficiently attach to lettuce veins and can internalize lettuce leafs during irrigation. The latter can lead to NoV contamination of the fresh produce (Gandhi et al. 2010; Li et al. 2012; Vega et al. 2005, 2008; Wei et al. 2010, 2011). River water, surface water, and ground water are frequently used for irrigation of crops (Knox et al. 2011; Steele and Odumeru 2004).
Furthermore, people can be infected with NoV via consumption of drinking water or via contact with recreational surface water (Bosch 1998; Moe et al. 2007). As a thorough overview of water related transmission routes for NoV and other viral pathogens has been described by Bosch et al. (1998), the current review will focus specifically on NoV transmission via river water, ground water, and surface water. It should be noted that direct comparison of studies investigating the NoV presence in water is difficult, as most studies use different NoV detection methodologies.

\section{River Water}

River water is likely to be contaminated with NoV as rivers are continuously fed with effluents of wastewater treatment plants, which are optimized for the removal of bacteria while removal viral pathogens could be less efficient (da Silva et al. 2007; Hewitt et al. 2011; Maunula et al. 2012; Ueki et al. 2005). The NoV presence in river water used for irrigation and used as drinking water has extensively been investigated in numerous screening worldwide and except for a single study (La Rosa et al. 2007), the NoV presence has been shown in all tested rivers (Haramoto et al. 2005; Jurzik et al. 2010; Laverick et al. 2004; Lee and Kim 2008; Lodder et al. 2010; Mans et al. 2012; Schets et al. 2008; Westrell et al. 2006). In some cases, other enteric viruses such as rotaviruses, enteroviruses, and adenoviruses have been detected simultaneously (Haramoto et al. 2005; He et al. 2011; Jurzik et al. 2010; Kishida et al. 2012; Kiulia et al. 2010; Lodder et al. 2010; Schets et al. 2008). Regarding the NoV concentrations found in river water used for irrigation, a broad range of NoV levels can be present, fluctuating between $12 \mathrm{NoV}$ genomic copies/l and $6.4 \times 10^{4} \mathrm{NoV}$ genomic copies/1, although most studies only indicated the presence/absence of $\mathrm{NoV}$ in water (Haramoto et al. 2005; Jurzik et al. 2010; Laverick et al. 2004; Lodder et al. 2010; Westrell et al. 2006). Overall, a broad range of NoV genotypes have been detected in river water. While some studies have shown the dominant presence of the GII.4 genotype (Blanco Fernandez et al. 2011; Lodder et al. 2010), most studies demonstrate the simultaneous presence of various NoV genotypes such as GI.4 and GI.5 alongside other less frequently observed NoV genotypes (La Rosa et al. 2007; Lee and Kim 2008; Mans et al. 2012). NoV levels in river water depend on whether sewage and other sources containing human fecal material is discharged and whether or not the sewage has been treated (Lodder et al. 2010; Teunis et al. 2009). Noteworthy, a seasonal variation in NoV levels has been observed in long-term studies as NoVs were in generally more frequently observed in winter and early spring (He et al. 2011; Kishida et al. 2012; Kitajima et al. 2009, 2011; 
Pérez-Sautu et al. 2012; Westrell et al. 2006). This seasonality is most likely related to a combination of (i) the fact that low temperatures are considered a good conservation method for viruses (Baert et al. 2009a) and (ii) higher prevalence of NoVs in the human population during winter (Ahmed 2012; Rohayem 2009).

\section{Ground Water}

The microbial quality of ground water is in general considered very good as this water type tends to be cooler, is protected from sunlight, and has less microbiological and biological activity (Feachem et al. 1983; Steele and Odumeru 2004). Nevertheless, several studies have investigated the presence of NoV and other enteric viruses in this water type (Barthe et al. 2007; Cheong et al. 2009; Gabrieli et al. 2009; Jung et al. 2011; Lee et al. 2011; Locas et al. 2008). Although some studies did not find NoV in well water, (Cheong et al. 2009; Locas et al. 2008), most studies did demonstrate the NoV presence in various ground water sources. A study investigating Italian ground water sources found $15 \%$ of sources positive (Gabrieli et al. 2009), while 18-42\% of samples from Korean ground water wells tested positive for NoV (Jung et al. 2011; Lee et al. 2011). Similar to the NoV screenings in river water, a broad range of NoV genotypes has been found in ground water screenings (Gabrieli et al. 2009; Lee et al. 2011). Seasonality of the NoV presence and NoV levels in ground water is not a thoroughly investigated topic, although Westrell et al. (2006) demonstrated a clear absence and the presence of NoV in summer and winter months, respectively. On the other hand, another long-term study did not find such an explicit seasonality (Lee et al. 2011). Further research is, therefore, needed to see whether NoVs display a similar seasonal pattern as enteroviruses, rotaviruses, and hepatitis A virus in ground water (Abbaszadegan et al. 2003). Regarding the use of fecal indicator organisms, no significant correlation could be shown in any study investigating the NoV presence in ground water. While some studies found the NoV presence despite the absence of indicator organisms (Barthe et al. 2007; Gabrieli et al. 2009), other studies did find indicator organisms such as E. coli and coliphages but they were not related to the NoV presence (Cheong et al. 2009; Jung et al. 2011). However, a recent study showed that a combination of different fecal indicators may be helpful, but that further research is needed to support this observation (Lee et al. 2011).

Several NoV outbreaks have been related to contaminated ground water. NoV GI.3 has been found in fecal samples and in ground water related to a $\mathrm{NoV}$ water borne outbreak affecting at least 84 people in Wyoming, USA (Parshionikar et al. 2003). In a water borne gastroenteritis outbreak involving bacterial and viral pathogens, $21 \%$ of all fecal samples tested NoV positive, although ground water as cause of the outbreak could only be determined by epidemiological data (Gallay et al. 2006).

\section{Surface Water}

Surface waters (e.g., lakes, bays, and recreational water) are a known transmission route for NoV, as an overview of water borne outbreaks between 2001 and 2004 associated with surface water showed that NoV was the responsible pathogen in $39.2 \%$ of outbreaks with a confirmed etiology (Dziuban et al. 2006; Yoder et al. 2004). Overall, only a limited number of studies have investigated the $\mathrm{NoV}$ presence in surface water. A Finnish study found 1 out of 7 investigated lakes positive for $\mathrm{NoV}$ between 2000 and 2001, while $50 \%$ of samples from an estuarine bay in Singapore tested positive for NoV (Aw et al. 2009; Horman et al. 2004). Similar to drinking water and ground water, fecal and chemical indicators have not been related to $\mathrm{NoV}$ contamination of surface water (Horman et al. 2004).

\section{Zoonotic Transmission}

The existence of a zoonotic reservoir for human infective NoV has been investigated, but zoonotic transmission of human infective NoV has thus far never been proven ( $\mathrm{Li}$ 2012). Nevertheless, the detection of human infective NoV in animal species in close contact with human beings raises suspicion for cross-species or zoonotic transmission and for the existence of an animal reservoir for human infective NoV (Mattison et al. 2007; Scipioni et al. 2008). Therefore, the animal and human infective NoV presence studies have been performed in different animals and an overview of these studies, based on the molecular detection of NoVs in feces from cattle and pigs, is presented in Tables 2 and 3, respectively. As the current review involved cooperation of a number of Belgian laboratories investigating animal $\mathrm{NoV}$, we were able to compare Belgian data to worldwide observations. For the Belgian perspective, diarrheic fecal samples from domestic animals were screened for the NoV presence between 2007 and 2008. NoV sequences were detected in various animal types. While animal $\mathrm{NoV}$ were found in cattle and pigs, all other domestic animal samples (poultry, sheep, equine, cats, and dogs) tested negative (Axel Mauroy, personal communication).

In Belgium, $7.5 \%$ (in 2007) and $9.3 \%$ (in 2008) of feces samples coming from diarrheic calves and young stock tested positive for the presence of bovine NoVs, with NoV GIII.2 being by far the most prevalent genotype in both studies (Mauroy et al. 2009a, b).

This data were in accordance with previously published studies from the United Kingdom, Hungary, Germany, and 


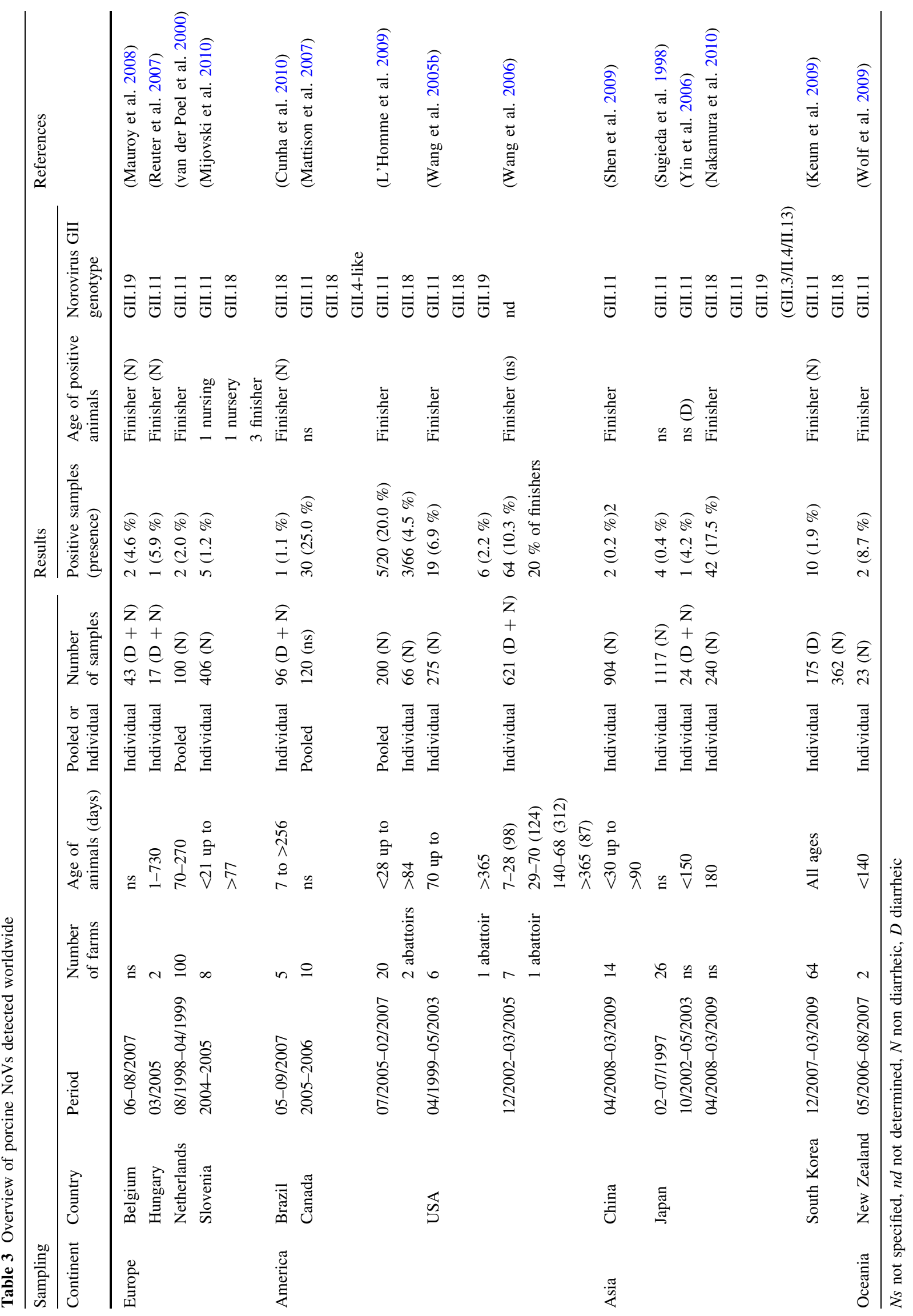


South Korea (Table 2) although other epidemiological data available from calf farms in industrialized countries indicated NoV prevalence ranging from 1.6 to $72 \%$. Similar to the Belgian results, a majority of NoV GIII.2 was also observed in most studies which may support the idea of the existence of predominating NoV genotypes that dispose of advantages upon other genotypes similar to what has been observed for GII.4 NoVs in humans (Kroneman et al. 2008; Siebenga et al. 2007; Verhoef et al. 2010, 2009). Interestingly, a single Belgian cattle sample showed a GIII.1/ GIII.2 co-infection while a potential recombinant strain between NoV GIII.1 and NoV GIII.2 was found in another sample. This recombinant strain was closely related to a previously described strain NoV GIII Thirsk in British and Norwegian cattle (Jor et al. 2010; Oliver et al. 2004).

A 3 month survey found $4.6 \%$ of Belgian pigs positive for porcine NoVs in 2007 (Mauroy et al. 2008). Although studies conducted in other industrialized countries found the NoV presence in pigs ranging between 0.2 and $25 \%$, Belgian results are congruent with data from Hungarian, Canadian, and Japanese pigs. Both NoV strains detected in Belgium clustered within the NoV GII.19 genotype. To date, porcine NoVs cluster into three GII genotypes and all three genotypes have been detected in Europe, America, and Asia (Wang et al. 2005b).

Worldwide and in Belgium, bovine and porcine NoV are widely endemic in their respective hosts, although data diverges greatly between studies (Tables 2, 3). These disparities observed could be explained by the use of different detection methods, the use of internal amplification controls for the detection of false negative results and different sampling strategies.

The clinical impact of bovine NoVs included watery diarrhea (Jor et al. 2010; Otto et al. 2011) while porcine NoV often causes an asymptomatic infection (Scipioni et al. 2008). Porcine NoV has exclusively been detected in fecal samples of finisher pigs ( $>10$ weeks old pigs) (Scipioni et al. 2008; Sugieda et al. 1998; van der Poel et al. 2000; Wang et al. 2005a). Finally, murine NoVs cause a mild gastroenteritis in mice (Liu et al. 2009a; Thackray et al. 2007). Noteworthy, multiple studies have already carefully suggested that recombination of porcine and human infective NoV, both belonging to genogroup II of the Norovirus genus, could be a hypothetical zoonotic transmission route (Bull et al. 2007; Phan et al. 2007; Wang et al. 2005a). Similarly, recombination between canine and human infective GIV NoVs may be possible (Martella et al. 2009), but more data is needed to confirm whether this could lead to zoonotic transmission of NoV. Interestingly, recombination on the ORF1/ORF2 junction has also been observed among murine NoVs (Matthijs et al. 2010).

Regarding the infection of animals with human infective NoV, several studies have demonstrated that this is possible in non-human primates, pigs, and pet dogs, resulting in no clinical symptoms to very mild gastroenteritis (Bok et al. 2011; Rockx et al. 2005; Summa et al. 2012b; Takanashi et al. 2011). On the other hand, antibodies for bovine NoVs have been detected in veterinarians and in the general population (Widdowson et al. 2005a). However, the number of studies investigating cross infection of animal and human infective $\mathrm{NoV}$ are limited and further research is needed to see whether human infective NoV can indeed be spread via animals.

\section{Conclusions}

Development of methods for molecular detection of human and animal infective NoVs has confirmed NoV transmission routes that were suspected by investigating NoV outbreaks before sequencing of the NoV genome (Greenberg et al. 1979; Gunn et al. 1982; Koopman et al. 1982; Sekla et al. 1989; White et al. 1986). Person-to-person transmission of NoVs is by far the dominant transmission route, but food and water borne transmission are also frequently observed transmission routes. A strategy to reduce or even prevent person-to-person transmission (and NoV transmission in general) could be the development of a NoV vaccine, based on the use of virus-like particles containing capsid antigens. Some hurdles such as longterm immunity and the need for immunity against multiple NoV genotypes exist, but comprehensive strain surveillance e.g., via web-based open-access genotyping tools (Kroneman et al. 2011) such as Noronet (http:// www.noronet.nl/noronet) and the use of multivalent vaccines may be a suitable approach for a vaccine development (Atmar et al. 2011; LoBue et al. 2006; Vinje 2010). Transmission of NoV by food handlers can easily lead to a NoV gastroenteritis outbreak. Both the Codex Alimentarius (2003) and the Food Code (2009) state that food handlers suffering from NoV gastroenteritis should not be allowed on the food preparation and handling areas. However, transmission of $\mathrm{NoV}$ via asymptomatic infected food handlers or via food handlers recovering from NoV gastroenteritis could be severely reduced by applying and respecting intervention measures (Mokhtari and Jaykus 2009). Regarding an approach to prevent NoV food borne outbreaks caused by pre-harvest contamination of bivalve molluscan shellfish, a critical limit has been suggested (Lowther et al. 2012), although both economical and public health aspects should be kept in mind (Anonymous 2012). The use of sensitive molecular NoV detection methods has shown that a substantial fraction of fresh produce can be contaminated with NoV while no associated NoV illness was reported (Baert et al. 2011). A possible solution could be confirmation of real-time PCR results using a different 
molecular detection assay (e.g., different primers and probes) (Baert et al. 2011). Furthermore, NoV can effectively be spread via water and has resulted in several NoV water borne outbreaks (Maunula 2006). As most water treatment plants are designed for removal of bacterial pathogens, NoV can still be present in treated wastewater (Katayama et al. 2008; Laverick et al. 2004; RodriguezLazaro et al. 2011; van den Berg et al. 2005). However, further research is needed to determine whether novel methods can sufficiently reduce the NoV presence in different water types (Springthorpe and Sattar 2007). Regarding the role of animal NoVs, molecular detection coupled with DNA sequencing has allowed numerous molecular epidemiological studies of NoVs in humans and in animals (Tables 2,3). These studies have led to the conclusion that NoV zoonotic transmission is unlikely to happen although it cannot be excluded.

Acknowledgments The authors are partners of the NORISK project, funded by the Belgian policy "Science for a Sustainable Development" (contract SD/AF/01). Furthermore, this work was supported by the Federal Public Service for Health, Food chain and Environment, Grant RT 10/6 (TRAVIFOOD), and by the Special Research Fund of the Ghent University.

\section{References}

Abbaszadegan, M., LeChevallier, M., \& Gerba, C. (2003). Occurrence of viruses IN US groundwaters. American Water Works Journal, 95(9), 107-120.

Ahmed, S. M. (2012). The global seasonality of norovirus gastroenteritis. Master's thesis.

Alcalá, A. C., Hidalgo, M. A., Obando, C., Vizzi, E., Liprandi, F., \& Ludert, J. E. (2003). Molecular identification of bovine enteric caliciviruses in Venezuela. Acta Cientifica Venezolana, 54(2), 148-152.

Anderson, A. D., Garrett, V. D., Sobel, J., Monroe, S. S., Fankhauser, R. L., Schwab, K. J., et al. (2001). Multistate outbreak of Norwalk-like virus gastroenteritis associated with a common caterer. American Journal of Epidemiology, 154(11), $1013-1019$.

Anonymous. (2000). Appendix B guidelines for confirmation of foodborne-disease outbreaks. Morbidity and Mortality Weekly Report, 49(SS01), 54-62.

Anonymous. (2009). FDA: Food code 2009. U.S. Public Health Service FDA, http://www.fda.gov/downloads/Food/FoodSafety/ RetailFoodProtection/FoodCode/FoodCode2009/ UCM189448.pdf.

Anonymous. (2010). Manual for the reporting of food-borne outbreaks in the framework of directive 2003/99/EC from the reporting year 2009. EFSA Journal, 8(4), 1578.

Anonymous. (2012). Scientific opinion on norovirus (NoV) in oysters: methods, limits and control options. EFSA Journal, 10(1), 2500.

Aoki, Y., Suto, A., Mizuta, K., Ahiko, T., Osaka, K., \& Matsuzaki, Y. (2010). Duration of norovirus excretion and the longitudinal course of viral load in norovirus-infected elderly patients. Journal of Hospital Infection, 75(1), 42-46.

Atmar, R. L., Bernstein, D. I., Harro, C. D., Al-Ibrahim, M. S., Chen, W. H., Ferreira, J., et al. (2011). Norovirus vaccine against experimental human Norwalk virus illness. New England Journal of Medicine, 365(23), 2178-2187.

Atmar, R. L., Opekun, A. R., Gilger, M. A., Estes, M. K., Crawford, S. E., Neill, F. H., et al. (2008). Norwalk virus shedding after experimental human infection. Emerging Infectious Diseases, 14(10), 1553-1557.

Aw, T. G., Gin, K. Y.-H., Ean Oon, L. L., Chen, E. X., \& Woo, C. H. (2009). Prevalence and genotypes of human noroviruses in tropical urban surface waters and clinical samples in Singapore. Applied and Environmental Microbiology, 75(15), 4984-4992.

Baert, L., Debevere, J., \& Uyttendaele, M. (2009a). The efficacy of preservation methods to inactivate foodborne viruses. International Journal of Food Microbiology, 131(2-3), 83-94.

Baert, L., Mattison, K., Loisy-Hamon, F., Harlow, J., Martyres, A., Lebeau, B., et al. (2011). Review: Norovirus prevalence in Belgian, Canadian and French fresh produce: A threat to human health? International Journal of Food Microbiology, 151(3), 261-269.

Baert, L., Uyttendaele, M., \& Debevere, J. (2008). Evaluation of viral extraction methods on a broad range of Ready-To-Eat foods with conventional and real-time RT-PCR for Norovirus GII detection. International Journal of Food Microbiology, 123(1-2), 101-108.

Baert, L., Uyttendaele, M., Stals, A., Van Coillie, E., Dierick, K., Debevere, J., et al. (2009b). Reported foodborne outbreaks due to noroviruses in Belgium: The link between food and patient investigations in an international context. Epidemiology and Infection, 137(3), 316-325.

Barthe, C., Locas, A., Barbeau, B., Carriere, A., \& Payment, P. (2007). Virus occurrence in municipal groundwater sources in Quebec, Canada. Canadian Journal of Microbiology, 53(6), 688-694.

Becker, K. M., Moe, C. L., Southwick, K. L., \& MacCormack, J. N. (2000). Transmission of Norwalk virus during a football game. New England Journal of Medicine, 343(17), 1223-1227.

Blanco Fernandez, M. D., Torres, C., Martinez, L. C., Giordano, M. O., Masachessi, G., Barril, P. A., et al. (2011). Genetic and evolutionary characterization of norovirus from sewage and surface waters in Cordoba City, Argentina. Infection, Genetics and Evolution, 11(7), 1631-1637.

Bohm, S. R., Brennan, B. M., Schirmer, R., \& Cabose, G. (2008). Norovirus outbreak associated with ill food-service workers: Michigan, January-February 2006 (Reprinted MMWR, vol 56, pg 1212-1216, 2007). Journal of the American Medical Association, 299(2), 164-166.

Bok, K., Abente, E. J., Realpe-Quintero, M., Mitra, T., Sosnovtsev, S. V., Kapikian, A. Z., et al. (2009). Evolutionary dynamics of GII. 4 Noroviruses over a thirty-four year period. Journal of Virology, 83(22), 11890-11901.

Bok, K., Parra, G. I., Mitra, T., Abente, E., Shaver, C. K., Boon, D., et al. (2011). Chimpanzees as an animal model for human norovirus infection and vaccine development. Proceedings of the National Academy of Sciences, 108(1), 325-330.

Bosch, A. (1998). Human enteric viruses in the water environment: A minireview. International Microbiology, 1(3), 191-196.

Boxman, I. L. A., Tilburg, J. J. H. C., Loeke, N. A. J. M., Vennema, H., de Boer, E., \& Koopmans, M. (2007). An efficient and rapid method for recovery of norovirus from food associated with outbreaks of gastroenteritis. Journal of Food Protection, 70(2), 504-508.

Boxman, I. L. A., Tilburg, J. J. H. C., Te Loeke, N. A. J. M., Vennema, H., Jonker, K., de Boer, E., et al. (2006). Detection of noroviruses in shellfish in the Netherlands. International Journal of Food Microbiology, 108(3), 391-396.

Bridger, J. C. (1980). Detection by electron microscopy of caliciviruses, astroviruses and rotavirus-like particles in the faeces of 
piglets with diarrhoea. The Veterinary Record, 107(23), 532-533.

Bull, R. A., Eden, J. S., Rawlinson, W. D., White, P. A. (2010). Rapid evolution of pandemic Noroviruses of the GII.4 Lineage. PLoS Pathogens, 6(3), e-1000831.

Bull, R. A., Tanaka, M. M., \& White, P. A. (2007). Norovirus recombination. Journal of General Virology, 88(12), 3347-3359.

Bull, R. A., \& White, P. A. (2011). Mechanisms of GII. 4 norovirus evolution. Trends in Microbiology, 19(5), 233-240.

Cheong, S., Lee, C., Song, S. W., Choi, W. C., Lee, C. H., \& Kim, S. J. (2009). Enteric viruses in raw vegetables and groundwater used for irrigation in South Korea. Applied and Environmental Microbiology, 75(24), 7745-7751.

Cieslak, P. R., Lee, L. E., Papafragkou, E., \& An, N. (2009). Recurring norovirus outbreaks in a long-term residential treatment facility-Oregon, 2007. Morbidity and Mortality Weekly Report, 58(25), 694-698.

Costas, L., Vilella, A., Llupia, A., Bosch, J., de Jimenez Anta, M. T., \& Trilla, A. (2007). Outbreak of norovirus gastroenteritis among staff at a hospital in Barcelona, Spain, September 2007. Euro Surveillance, 12(11), E071122.5.

Cotterelle, B., Drougard, C., Rolland, J., Becamel, M., Boudon, M., Pinede, S., et al. (2005). Outbreak of norovirus infection associated with the consumption of frozen raspberries, France, March 2005. Euro Surveillance, 10(17), E050428.1.

Croci, L., Losio, M. N., Suffredini, E., Pavoni, E., Di Pasquale, S., Fallacara, F., et al. (2007). Assessment of human enteric viruses in shellfish from the northern Adriatic sea. International Journal of Food Microbiology, 114(2), 252-257.

Cunha, J. B., De Mendonça, M. C. L., Miagostovich, M. P., \& Leite, J. P. G. (2010). Genetic diversity of porcine enteric caliciviruses in pigs raised in Rio de Janeiro State, Brazil. Archives of Virology, 155(8), 1301-1305.

da Silva, A. K., Le Saux, J. C., Parnaudeau, S., Pommepuy, M., Elimelech, M., \& Le Guyader, F. S. (2007). Evaluation of removal of noroviruses during wastewater treatment, using realtime reverse transcription-PCR: Different behaviors of genogroups I and II. Applied and Environmental Microbiology, 73(24), 7891-7897.

Daniels, N. A., Bergmire-Sweat, D. A., Schwab, K. J., Hendricks, K. A., Reddy, S., Rowe, S. H., et al. (2000). A foodborne outbreak of gastroenteritis associated with Norwalk-like viruses: First molecular traceback to deli sandwiches contaminated during preparation. Journal of Infectious Diseases, 181(4), 1467-1470.

David, S. T., McIntyre, L., MacDougall, L., Kelly, D., Liem, S., Schallie, K., et al. (2007). An outbreak of norovirus caused by consumption of oysters from geographically dispersed harvest sites, British Columbia, Canada, 2004. Foodborne Pathogens and Disease, 4(3), 349-358.

de Coster, E., de Wit, M., \& Widdowson, M. (2001). Large outbreak of Norwalk-like virus in ministry staff in the Netherlands. Euro Surveillance, 5(1), 1-2.

De Wit, M. A. S., Widdowson, M. A., Vennema, H., de Bruin, E., Fernandes, T., \& Koopmans, M. (2007). Large outbreak of norovirus: The baker who should have known better. Journal of Infection, 55(2), 188-193.

Deng, Y., Batten, C. A., Liu, B. L., Lambden, P. R., Elschner, M., Günther, H., et al. (2003). Studies of epidemiology and seroprevalence of bovine noroviruses in Germany. Journal of Clinical Microbiology, 41(6), 2300-2305.

Dippold, L., Lee, R., Selman, C., Monroe, S., \& Henry, C. (2003). A gastroenteritis outbreak due to norovirus associated with a Colorado hotel. Journal of Environmental Health, 66(5), 13-26.

Dziuban, E. J., Liang, J. L., Craun, G. F., Hill, V., Yu, P. A., Painter, J., et al. (2006). Surveillance for waterborne disease and outbreaks associated with recreational water-United States,
2003-2004. Morbidity and Mortality Weekly Report, 55(12), $1-30$.

Escudero, B. I., Rawsthorne, H., Gensel, C., \& Jaykus, L. A. (2012). Persistence and transferability of noroviruses on and between common surfaces and foods. Journal of Food Protection, 75(5), 927-935.

Ethelberg, S., Lisby, M., Bottiger, B., Schultz, A. C., Villif, A., Jensen, T., et al. (2010). Outbreaks of gastroenteritis linked to lettuce, Denmark, January 2010. Eurosurveillance, 15(6), 2-4.

Falkenhorst, G., Krusell, L., Lisby, M., Madsen, S. B., Bottiger, B., \& Molbak, K. (2005). Imported frozen raspberries cause a series of norovirus outbreaks in Denmark, 2005. Euro Surveillance, 10(9), E050922.2.

Feachem, R., Mara, D. D., \& Bradley, D. J. (1983). Sanitation and disease: Health aspects of excreta and wastewater management (p. 294). Dorchester: Wiley.

Fretz, R., Svoboda, P., Luthi, T. M., Tanner, M., \& Baumgartner, A. (2005). Outbreaks of gastroenteritis due to infections with Norovirus in Switzerland, 2001-2003. Epidemiology and Infection, 133(3), 429-437.

Friedman, D. S., Heisey-Grove, D., Argyros, F., Berl, E., Nsubuga, J., Stiles, T., et al. (2005). An outbreak of norovirus gastroenteritis associated with wedding cakes. Epidemiology and Infection, 133(6), 1057-1063.

Gabrieli, R., Maccari, F., Ruta, A., Pana, A., \& Divizia, M. (2009). Norovirus detection in groundwater. Food and Environmental Virology, 1(2), 92-96.

Gallay, A., De Valk, H., Cournot, M., Ladeuil, B., Hemery, C., Castor, C., et al. (2006). A large multi-pathogen waterborne community outbreak linked to faecal contamination of a groundwater system, France, 2000. Clinical Microbiology and Infection, 12(6), 561-570.

Gallimore, C. I., Barreiros, M. A. B., Brown, D. W. G., Nascimento, J. P., \& Leite, J. P. G. (2004a). Noroviruses associated with acute gastroenteritis in a children's day care facility in Rio de Janeiro, Brazil. Brazilian Journal of Medical and Biological Research, 37(3), 321-326

Gallimore, C. I., Cheesbrough, J. S., Lamden, K., Bingham, C., Graya, J. J., \& Gray, J. J. (2005). Multiple norovirus genotypes characterised from an oyster-associated outbreak of gastroenteritis. International Journal of Food Microbiology, 103(3), 323-330.

Gallimore, C. I., Cubitt, D., Du Plessis, N., \& Gray, J. J. (2004b). Asymptomatic and symptomatic excretion of noroviruses during a hospital outbreak of gastroenteritis. Journal of Clinical Microbiology, 42(5), 2271-2274.

Gandhi, K. M., Mandrell, R. E., \& Tian, P. (2010). Binding of viruslike particles of Norwalk virus to romaine lettuce veins. Applied and Environmental Microbiology, 76(24), 7997-8003.

Glasscock, S., Welch, J., Dailer, J., Elmer, W., Kline, K., del Rosario, M., et al. (2007). Multistate outbreak of norovirus gastroenteritis among attendees at a family reunion-Grant County, West Virginia, October 2006. Morbidity and Mortality Weekly Report, 56(27), 673-678.

Godoy, P., Izcara, J., Bartolome, R., Bach, P., Escobar, A., Pal, M., et al. (2005). Outbreak of food-borne Norovirus associated with the consumption of sandwiches. Medicina Clinica, 124(5), 161-164.

Green, K. Y., Ando, T., Balayan, M. S., Berke, T., Clarke, I. N., Estes, M. K., et al. (2000). Taxonomy of the caliciviruses. Journal of Infectious Diseases, 181, S322-S330.

Greenberg, H. R., Valdesuso, J., Yolken, R. H., Gangarosa, E., Gary, W., Wyatt, R. G., et al. (1979). Role of Norwalk virus in outbreaks of nonbacterial gastroenteritis. Journal of Infectious Diseases, 139(5), 564-568.

Greening, G. E. (2006). Human and animal viruses in food (including taxonomy of enteric viruses). In S. M. Goyal (Ed.), Viruses in foods (p. 5). New York: Springer. 
Grotto, I., Huerta, M., Balicer, R. D., Halperin, T., Cohen, D., Orr, N., et al. (2004). An outbreak of norovirus gastroenteritis on an Israeli military base. Infection, 32(6), 339-343.

Gunn, R. A., Janowski, H. T., Lieb, S. P. E. N., Prather, E. C., \& Greenberg, H. B. (1982). Norwalk virus gastroenteritis following raw oyster consumption. American Journal of Epidemiology, 115(3), 348-351.

Haramoto, E., Katayama, H., Oguma, K., \& Ohgaki, S. (2005). Application of cation-coated filter method to detection of noroviruses, enteroviruses, adenoviruses, and torque teno viruses in the Tamagawa River in Japan. Applied and Environmental Microbiology, 71(5), 2403-2411.

He, X., Wei, Y., Cheng, L., Zhang, D., \& Wang, Z. (2011). Molecular detection of three gastroenteritis viruses in urban surface waters in Beijing and correlation with levels of fecal indicator bacteria. Environmental Monitoring and Assessment, 184(9), 5563-5570.

Hewitt, J., Leonard, M., Greening, G. E., \& Lewis, G. D. (2011). Influence of wastewater treatment process and the population size on human virus profiles in wastewater. Water Research, 45(18), 6267-6276.

Hirakata, Y., Arisawa, K., Nishio, O., \& Nakagomi, O. (2005). Multiprefectural spread of gastroenteritis outbreaks attributable to a single genogroup II norovirus strain from a tourist restaurant in Nagasaki, Japan. Journal of Clinical Microbiology, 43(3), 1093-1098.

Hjertqvist, M., Johansson, A., Svensson, N., Abom, P. E., Magnusson, C., Olsson, M., et al. (2006). Four outbreaks of norovirus gastroenteritis after consuming raspberries, Sweden, JuneAugust 2006. Euro Surveillance, 11(9), E060907.1.

Horman, A., Rimhanen-Finne, R., Maunula, L., von Bonsdorff, C. H., Torvela, N., Heikinheimo, A., et al. (2004). Campylobacter spp., Giardia spp., Cryptosporidium noroviruses and indicator organisms in surface water in southwestern Finland, 2000-2001. Applied and Environmental Microbiology, 70(1), 87-95.

Ike, A. C., Roth, B. N., Böhm, R., Pfitzner, A. J., \& Marschang, R. E. (2007). Identification of bovine enteric Caliciviruses (BEC) from cattle in Baden-Württemberg. DTW. Deutsche Tierarztliche Wochenschrift, 114(1), 12-15.

Johansson, P. J. H., Torven, M., Hammarlund, A. C., Bjorne, U., Hedlund, K. O., \& Svensson, L. (2002). Food-borne outbreak of gastroenteritis associated with genogroup I calicivirus. Journal of Clinical Microbiology, 40(3), 794-798.

Joint FAO/WHO Codex Alimentarius Commission, \& Joint FAO/ WHO Food Standards Program. (2003). Codex alimentarius: Food hygiene, basic texts.

Jor, E., Myrmel, M., \& Jonassen, C. M. (2010). SYBR Green based real-time RT-PCR assay for detection and genotype prediction of bovine noroviruses and assessment of clinical significance in Norway. Journal of Virological Methods, 169(1), 1-7.

Jung, J. H., Yoo, C. H., Koo, E. S., Kim, H. M., Na, Y., Jheong, W. H., et al. (2011). Occurrence of norovirus and other enteric viruses in untreated groundwaters of Korea. Journal of Water and Health, 9(3), 544-555.

Jurzik, L., Hamza, I. A., Puchert, W., Überla, K., \& Wilhelm, M. (2010). Chemical and microbiological parameters as possible indicators for human enteric viruses in surface water. International Journal of Hygiene and Environmental Health, 213(3), 210-216.

Kapikian, A. Z., Wyatt, R. G., Dolin, R., Thornhill, T. S., Kalica, A. R., \& Chanock, R. M. (1972). Visualization by immune electron microscopy of a 27-nm particle associated with acute infectious nonbacterial gastroenteritis. Journal of Virology, 10(5), 1075-1081.

Katayama, H., Haramoto, E., Oguma, K., Yamashita, H., Tajima, A., Nakajima, H., et al. (2008). One-year monthly quantitative survey of noroviruses, enteroviruses, and adenoviruses in wastewater collected from six plants in Japan. Water Research, 42(6-7), 1441-1448.

Keum, H., Moon, H., Park, S., Kim, H., Rho, S., \& Park, B. (2009). Porcine noroviruses and sapoviruses on Korean swine farms. Archives of Virology, 154(11), 1765-1774.

Kiehl, W., Schreier, E., Twisselman, B., \& Wunderle, W. (2001). Outbreak of Norwalk-like infection in Germany. Eurosurveillance, 5(15), 1.

Kingsley, D. H., Meade, G. K., \& Richards, G. P. (2002). Detection of both hepatitis A virus and Norwalk-like virus in imported clams associated with food-borne illness. Applied and Environmental Microbiology, 68(8), 3914-3918.

Kishida, N., Morita, H., Haramoto, E., Asami, M., \& Akiba, M. (2012). One-year weekly survey of noroviruses and enteric adenoviruses in the Tone River water in Tokyo metropolitan area, Japan. Water Research, 46(9), 2905-2910.

Kitajima, M., Haramoto, E., Phanuwan, C., Katayama, H., \& Ohgaki, S. (2009). Detection of genogroup IV norovirus in wastewater and river water in Japan. Letters in Applied Microbiology, 49(5), $655-658$.

Kitajima, M., Oka, T., Haramoto, E., Phanuwan, C., Takeda, N., Katayama, K., et al. (2011). Genetic diversity of genogroup IV noroviruses in wastewater in Japan. Letters in Applied Microbiology, 52(2), 181-184.

Kiulia, N. M., Netshikweta, R., Page, N. A., van Zyl, W. B., Kiraithe, M. M., Nyachieo, A., et al. (2010). The detection of enteric viruses in selected urban and rural river water and sewage in Kenya, with special reference to rotaviruses. Journal of Applied Microbiology, 109(3), 818-828.

Knox, J. W., Tyrrel, S. F., Daccache, A., \& Weatherhead, E. K. (2011). A geospatial approach to assessing microbiological water quality risks associated with irrigation abstraction. Water and Environment Journal, 25(2), 282-289.

Koopman, J. S., Eckert, E. A., Greenberg, H. B., Strohm, B. C., Isaacson, R. E., \& Monto, A. S. (1982). Norwalk virus enteric illness acquired by swimming exposure. American Journal of Epidemiology, 115(2), 173-177.

Koopmans, M. (2009). Noroviruses in healthcare settings: A challenging problem. Journal of Hospital Infection, 73(4), 331-337.

Koopmans, M., \& Duizer, E. (2004). Foodborne viruses: An emerging problem. International Journal of Food Microbiology, 90(1), 23-41.

Kroneman, A., Vennema, H., Deforche, K., Avoort, H. V. D., Penaranda, S., Oberste, M. S., et al. (2011). An automated genotyping tool for enteroviruses and noroviruses. Journal of Clinical Virology, 51(2), 121-125.

Kroneman, A., Verhoef, L., Harris, J., Vennema, H., Duizer, E., van Duynhoven, Y., et al. (2008). Analysis of integrated virological and epidemiological reports of norovirus outbreaks collected within the Foodborne Viruses in Europe Network from 1 July 2001 to 30 June 2006. Journal of Clinical Microbiology, 46(9), 2959-2965.

Kuo, H. W., Schmid, D., Jelovcan, S., Pichler, A. M., Magnet, E., Reichart, S., et al. (2009). A foodborne outbreak due to Norovirus in Austria, 2007. Journal of Food Protection, 72(1), 193-196.

La Rosa, G., Fontana, S., Di Grazia, A., Iaconelli, M., Pourshaban, M., \& Muscillo, M. (2007). Molecular identification and genetic analysis of norovirus genogroups I and II in water environments: Comparative analysis of different reverse transcription-PCR assays (vol 73, pg 4152). Applied and Environmental Microbiology, 73(19), 6329.

Lamhoujeb, S., Fliss, I., Ngazoa, S. E., \& Jean, J. (2009). Molecular study of the persistence of infectious human Norovirus on foodcontact surfaces. Food and Environmental Virology, 1(2), 51-56. 
Laverick, M. A., Wyn-Jones, A. P., \& Carter, M. J. (2004). Quantitative RT-PCR for the enumeration of noroviruses (Norwalk-like viruses) in water and sewage. Letters in Applied Microbiology, 39(2), 127-136.

Le Guyader, F. S., Bon, F., DeMedici, D., Parnaudeau, S., Bertone, A., Crudeli, S., et al. (2006). Detection of multiple noroviruses associated with an international gastroenteritis outbreak linked to oyster consumption. Journal of Clinical Microbiology, 44(11), 3878-3882.

Le Guyader, F. S., Le Saux, J. C., Ambert-Balay, K., Krol, J., Serais, O., Parnaudeau, S., et al. (2008). Aichi virus, norovirus, astrovirus, enterovirus, and rotavirus involved in clinical cases from a French oyster-related gastroenteritis outbreak. Journal of Clinical Microbiology, 46(12), 4011-4017.

Le Guyader, F. S., Mittelholzer, C., Haugarreau, L., Hedlund, K. O., Alsterlund, R., Pommepuy, M., et al. (2004). Detection of noroviruses in raspberries associated with a gastroenteritis outbreak. International Journal of Food Microbiology, 97(2), 179-186.

Le Guyader, F. S., Neill, F. H., Dubois, E., Bon, F., Loisy, F., Kohli, E., et al. (2003). A semiquantitative approach to estimate Norwalk-like virus contamination of oysters implicated in an outbreak. International Journal of Food Microbiology, 87(1-2), 107-112.

Lederer, I., Schmid, D., Pichler, A. M., Dapra, R., Kraler, P., Blassnig, A., et al. (2005). Outbreak of norovirus infections associated with consuming food from a catering company, Austria, September 2005. Euro Surveillance, 10(10), E051020.7.

Lee, N., Chan, M. C. W., Wong, B., Choi, K. W., Sin, W., Lui, G., et al. (2007). Fecal viral concentration and diarrhea in norovirus gastroenteritis. Emerging Infectious Diseases, 13(9), 1399-1401.

Lee, C., \& Kim, S. J. (2008). The genetic diversity of human noroviruses detected in river water in Korea. Water Research, 42(17), 4477-4484.

Lee, H., Kim, M., Lee, J. E., Lim, M. Y., Kim, M. J., Kim, J. M., et al. (2011). Investigation of norovirus occurrence in groundwater in metropolitan Seoul, Korea. Science of the Total Environment, 409(11), 2078-2084.

L'Homme, Y., Sansregret, R., Plante-Fortier, E., Lamontagne, A. M., Ouardani, M., Lacroix, G., et al. (2009). Genomic characterization of swine caliciviruses representing a new genus of Caliciviridae. Virus Genes, 39(1), 66-75.

Li, J. (2012). New interventions against human Norovirus: Progresses, challenges, and opportunities. Annual Review of Food Science and Technology, 3(1), 331-352.

Li, D., Baert, L., Xia, M., Zhong, W., Jiang, X., \& Uyttendaele, M. (2012). Effects of a variety of food extracts and juices on the specific binding ability of Norovirus GII. 4 P particles. Journal of Food Protection, 75(7), 1350-1354.

Liu, P. B., Chien, Y. W., Papafragkou, E., Hsiao, H. M., Jaykus, L. A., \& Moe, C. (2009a). Persistence of human noroviruses on food preparation surfaces and human hands. Food and Environmental Virology, 1(3-4), 141-147.

Liu, G., Kahan, S. M., Jia, Y., \& Karst, S. M. (2009b). Primary highdose murine norovirus 1 infection fails to protect from secondary challenge with homologous virus. Journal of Virology, 83(13), 6963-6968.

LoBue, A. D., Lindesmith, L., Yount, B., Harrington, P. R., Thompson, J. M., Johnston, R. E., et al. (2006). Multivalent norovirus vaccines induce strong mucosal and systemic blocking antibodies against multiple strains. Vaccine, 24(24), 5220-5234.

Locas, A., Barthe, C., Margolin, A. B., \& Payment, P. (2008). Groundwater microbiological quality in Canadian drinking water municipal wells. Canadian Journal of Microbiology, 54(6), $472-478$

Lodder, W. J., \& de Roda Husman, A. M. (2005). Presence of noroviruses and other enteric viruses in sewage and surface waters in The Netherlands. Applied and Environmental Microbiology, 71(3), 1453-1461.

Lodder, W. J., van den Berg, H., Rutjes, S. A., \& de Roda Husman, A. M. (2010). Presence of enteric viruses in source waters for drinking water production in The Netherlands. Applied and Environmental Microbiology, 76(17), 5965-5971.

Lopman, B. A., Adak, G. K., Reacher, M. H., \& Brown, D. W. G. (2003). Two epidemiologic patterns of Norovirus outbreaks: Surveillance in England and Wales, 1992-2000. Emerging Infectious Diseases, 9(1), 71-77.

Lopman, B. A., Brown, D. W., \& Koopmans, M. (2002). Human caliciviruses in Europe. Journal of Clinical Virology, 24(3), 137-160.

Lowther, J. A., Gustar, N. E., Hartnell, R. E., \& Lees, D. N. (2012). Comparison of norovirus RNA levels in outbreak-related oysters with background environmental levels. Journal of Food Protection, 75(2), 389-393.

Lowther, J. A., Henshilwood, K., \& Lees, D. N. (2008). Determination of norovirus contamination in oysters from two commercial harvesting areas over an extended period, using semiquantitative real-time reverse transcription PCR. Journal of Food Protection, 71(7), $1427-1433$.

Makary, P., Maunula, L., Niskanen, T., Kuusi, M., Virtanen, M., Pajunen, S., et al. (2009). Multiple norovirus outbreaks among workplace canteen users in Finland, July 2006. Epidemiology and Infection, 137(3), 402-407.

Malek, M., Barzilay, E., Kramer, A., Camp, B., Jaykus, L. A., EscuderoAbarca, B., et al. (2009). Outbreak of norovirus infection among river rafters associated with packaged delicatessen meat, Grand Canyon, 2005. Clinical Infectious Diseases, 48(1), 31-37.

Mans, J., Netshikweta, R., Magwalivha, M., van Zyl, W. B., Taylor, M. B. (2012). Diverse norovirus genotypes identified in sewagepolluted river water in South Africa. Epidemiology and Infection, 1-11 (Epub ahead of print).

Martella, V., Campolo, M., Lorusso, E., Cavicchio, P., Camero, M., Bellacicco, A. L., et al. (2007). Norovirus in captive lion cub (Panthera leo). Emerging Infectious Diseases, 13, 1071-1073.

Martella, V., Decaro, N., Lorusso, E., Radogna, A., Moschidou, P., Amorisco, F., et al. (2009). Genetic heterogeneity and recombination in canine noroviruses. Journal of Virology, 83(21), 11391-11396.

Martella, V., Lorusso, E., Decaro, N., Elia, G., Radogna, A., D'Abramo, M., et al. (2008). Detection and molecular characterization of a canine norovirus. Emerging Infectious Diseases, 14(8), 1306-1308.

Matthijs, E., Muylkens, B., Mauroy, A., Ziant, D., Delwiche, T., \& Thiry, E. (2010). Experimental evidence of recombination in murine noroviruses. Journal of General Virology, 91(11), $2723-2733$.

Mattison, K., Harlow, J., Morton, V., Cook, A., Pollari, F., \& Bidawid, S. (2010). Enteric viruses in ready-to-eat packaged leafy greens. Emerging Infectious Diseases, 16(11), 1815-1817.

Mattison, K., Shukla, A., Cook, A., Pollari, F., Friendship, R., Kelton, D., et al. (2007). Human noroviruses in swine and cattle. Emerging Infectious Diseases, 13(8), 1184-1188.

Maunula, L. (2006). Waterborne norovirus outbreaks. Future Virology, 2(1), 101-112.

Maunula, L., Roivainen, M., Keranen, M., Makela, S., Soderberg, K., Summa, M., et al. (2009). Detection of human norovirus from frozen raspberries in a cluster of gastroenteritis outbreaks. Eurosurveillance, 14(49), 16-18.

Maunula, L., Söderberg, K., Vahtera, H., Vuorilehto, V. P., von Bonsdorff, C. H., Valtari, M., et al. (2012). Presence of human noro-and adenoviruses in river and treated wastewater, a longitudinal study and method comparison. Journal of Water and Health, 10(1), 87-99. 
Mauroy, A., Scipioni, A., Mathijs, E., Saegerman, C., Mast, J., Bridger, J. C., et al. (2009a). Epidemiological study of bovine norovirus infection by RT-PCR and a VLP-based antibody ELISA. Veterinary Microbiology, 137(3-4), 243-251.

Mauroy, A., Scipioni, A., Mathijs, E., Thys, C., \& Thiry, E. (2009b). Molecular detection of kobuviruses and recombinant noroviruses in cattle in continental Europe. Archives of Virology, 154(11), $1841-1845$.

Mauroy, A., Scipioni, A., Matthijs, E., Miry, C., Ziant, D., Thys, C., et al. (2008). Noroviruses and sapoviruses in pigs in Belgium. Archives of Virology, 153(10), 1927-1931.

Medici, M. C., Morelli, A., Arcangeletti, M. C., Calderaro, A., De Conto, F., Martinelli, M., et al. (2008). An outbreak of norovirus infection in an Italian residential-care facility for the elderly. Clinical Microbiology and Infection: The Official Publication of the European Society of Clinical Microbiology and Infections Diseases, 15(1), 97-100.

Mesquita, J. R., \& Nascimento, M. S. J. (2009). A foodborne outbreak of norovirus gastroenteritis associated with a christmas dinner in Porto, Portugal, December 2008. Eurosurveillance, 14(41), 19-21.

Meyers, T. R. (1984). Marine bivalve mollusks as reservoirs of viral finfish pathogens: Significance to marine and anadromous finfish aquaculture. Marine Fisheries Review, 46(3), 14-17.

Mijovski, J. Z., Poljsak-Prijatelj, M., Steyer, A., Barlic-Maganja, D., \& Koren, S. (2010). Detection and molecular characterisation of noroviruses and sapoviruses in asymptomatic swine and cattle in Slovenian farms. Infection, Genetics and Evolution, 10(3), $413-420$

Milnes, A. S., Binns, S. H., Oliver, S. L., \& Bridger, J. C. (2007). Retrospective study of noroviruses in samples of diarrhoea from cattle, using the Veterinary Laboratories Agency's Farmfile database. Veterinary Record, 160(10), 326-330.

Moe, C. L. (2007). Waterborne transmission of infectious agents. In C. J. Hurst, R. L. Crawford, J. L. Garland, D. A. Lipson, A. L. Mills, \& L. D. Stetzenbach (Eds.), Manual of environmental microbiology (pp. 222-248). Washington, DC: ASM Press.

Moe, C. L. (2008). Preventing norovirus transmission: How should we handle food handlers? Clinical Infectious Diseases, 48(1), $38-40$.

Mokhtari, A., \& Jaykus, L. A. (2009). Quantitative exposure model for the transmission of norovirus in retail food preparation. International Journal of Food Microbiology, 133(1-2), 38-47.

Morioka, S., Sakata, T., Tamaki, A., Shioji, T., Funaki, A., Yamamoto, Y., et al. (2006). A food-borne norovirus outbreak at a primary school in Wakayama Prefecture. Japanese Journal of Infectious Diseases, 59(3), 205-207.

Nakamura, K., Saga, Y., Iwai, M., Obara, M., Horimoto, E., Hasegawa, S., et al. (2010). Frequent detection of noroviruses and sapoviruses in swine population and high genetic diversity of porcine sapovirus in Japan, during fiscal year 2008. Journal of Clinical Microbiology, 48(4), 1215-1222.

Nenonen, N. P., Hannoun, C., Olsson, M. B., \& Bergstrom, T. (2009). Molecular analysis of an oyster-related norovirus outbreak. Journal of Clinical Virology, 45(2), 105-108.

Ng, T. L., Chan, P. P., Phua, T. H., Loh, J. P., Yip, R., Wong, C., et al. (2005). Oyster-associated outbreaks of Norovirus gastroenteritis in Singapore. Journal of Infection, 51(5), 413-418.

Nishida, T., Nishio, O., Kato, M., Chuma, T., Kato, H., Iwata, H., et al. (2007). Genotyping and quantitation of noroviruses in oysters from Two Distinct Sea areas in Japan. Microbiology and Immunology, 51(2), 177-184.

Noda, M., Fukuda, S., \& Nishio, O. (2008). Statistical analysis of attack rate in norovirus foodborne outbreaks. International Journal of Food Microbiology, 122(1-2), 216-220.

Nordgren, J., Kindberg, E., Lindgren, P. E., Matussek, A., \& Svensson, L. (2010). Norovirus gastroenteritis outbreak with a secretor-independent susceptibility pattern, Sweden. Emerging Infectious Diseases, 16(1), 81-87.

O’Brien, S. J., Gillespie, I. A., Sivanesan, M. A., Elson, R., Hughes, C., \& Adak, G. K. (2006). Publication bias in foodborne outbreaks of infectious intestinal disease and its implications for evidence-based food policy. England and Wales 1992-2003. Epidemiology and Infection, 134(04), 667-674.

Ohwaki, K., Nagashima, H., Aoki, M., Aoki, H., \& Yano, E. (2009). A foodborne norovirus outbreak at a hospital and an attached long-term care facility. Japanese Journal of Infectious Diseases, 62(6), 450-454.

Oliver, S. L., Brown, D. W. G., Green, J., \& Bridger, J. C. (2004). A chimeric bovine enteric calicivirus: Evidence for genomic recombination in genogroup III of the Norovirus genus of the Caliciviridae. Virology, 326(2), 231-239.

Oliver, S. L., Dastjerdi, A. M., Wong, S., El-Attar, L., Gallimore, C., Brown, D. W. G., et al. (2003). Molecular characterization of bovine enteric caliciviruses: a distinct third genogroup of noroviruses (Norwalk-like viruses) unlikely to be of risk to humans. Journal of Virology, 77(4), 2789-2798.

Oogane, T., Hirata, A., Funatogawa, K., Kobayashi, K., Sato, T., \& Kimura, H. (2008). Food poisoning outbreak caused by norovirus GII/4 in school lunch, Tochigi Prefecture, Japan. Japanese Journal of Infectious Diseases, 61(5), 423-424.

Otto, P. H., Clarke, I. N., Lambden, P. R., Salim, O., Reetz, J., \& Liebler-Tenorio, E. M. (2011). Infection of calves with bovine norovirus GIII. 1 strain jena virus: an experimental model to study the pathogenesis of norovirus infection. Journal of Virology, 85(22), 12013-12021.

Ozawa, K., Oka, T., Takeda, N., \& Hansman, G. S. (2007). Norovirus infections in symptomatic and asymptomatic food handlers in Japan. Journal of Clinical Microbiology, 45(12), 3996-4005.

Parasidis, T., Divari, E., Fatouros, N., \& Vantarakis, A. (2007). Outbreak of acute gastroenteritis in Greece during a school excursion, April 2007. Euro Surveillance, 12(7), E0705-E0707.

Park, S. I., Jeong, C., Kim, H. H., Park, S. H., Park, S. J., Hyun, B. H., et al. (2007). Molecular epidemiology of bovine noroviruses in South Korea. Veterinary Microbiology, 124(1-2), 125-133.

Parshionikar, S. U., Willian-True, S., Fout, G. S., Robbins, D. E., Seys, S. A., Cassady, J. D., et al. (2003). Waterborne outbreak of gastroenteritis associated with a norovirus. Applied and Environmental Microbiology, 69(9), 5263-5268.

Patel, M. M., Hall, A. J., Vinje, J., \& Parashar, U. D. (2009). Noroviruses: A comprehensive review. Journal of Clinical Virology: The Official Publication of the Pan American Society for Clinical Virology, 44(1), 1-8.

Payne, K., Hall, M., Lutzke, M., Armstrong, C., \& King, J. (2006). Multisite outbreak of norovirus associated with a franchise restaurant-Kent County, Michigan, May 2005. Morbidity and Mortality Weekly Report, 55(14), 395-397.

Pérez-Sautu, U., Sano, D., Guix, S., Kasimir, G., Pinto, R. M., \& Bosch, A. (2012). Human norovirus occurrence and diversity in the Llobregat river catchment, Spain. Environmental Microbiology, 14(2), 494-502.

Phan, T. G., Kaneshi, K., Ueda, Y., Nakaya, S., Nishimura, S., Yamamoto, A., et al. (2007). Genetic heterogeneity, evolution, and recombination in noroviruses. Journal of Medical Virology, 79(9), 1388-1400.

Phillips, G., Tam, C. C., Rodrigues, L. C., \& Lopman, B. (2010). Prevalence and characteristics of asymptomatic norovirus infection in the community in England. Epidemiology and Infection, 139(11), 1-5.

Pinto, P., Wang, Q., Chen, N., Dubovi, E. J., Daniels, J. B., Millward, L. M., et al. (2012). Discovery and genomic characterization of noroviruses from a gastroenteritis outbreak in domestic cats in the US. PLoS One, 7(2), e-32739. 
Prato, R., Lopalco, P. L., Chironna, M., Barbuti, G., Germinario, C., \& Quarto, M. (2004). Norovirus gastroenteritis general outbreak associated with raw shellfish consumption in south Italy. BMC Infectious Disease, 6(37), 1-6.

Reuter, G., Biro, H., \& Szucs, G. (2007). Enteric caliciviruses in domestic pigs in Hungary. Archives of Virology, 152(3), 611-614.

Reuter, G., Pankovics, P., \& Egyed, L. (2009). Detection of genotype 1 and 2 bovine noroviruses in Hungary. Veterinary Record, 165(18), 537-538.

Rizzo, C., Di Bartolo, I., Santantonio, M., Coscia, M. F., Monno, R., De Vito, D., et al. (2007). Epidemiological and virological investigation of a Norovirus outbreak in a resort in Puglia, Italy. BMC Infectious Diseases, 7, 135.

Rockx, B. H. G., Bogers, W., Heeney, J. L., van Amerongen, G., \& Koopmans, M. P. G. (2005). Experimental norovirus infections in non-human primates. Journal of Medical Virology, 75(2), 313-320.

Rodriguez-Lazaro, D., Cook, N., Ruggeri, F. M., Sellwood, J., Nasser, A., Nascimento, M. S. J., et al. (2011). Virus hazards from food, water and other contaminated environments. FEMS Microbiology Reviews, 36(4), 786-814.

Rohayem, J. (2009). Norovirus seasonality and the potential impact of climate change. Clinical Microbiology \& Infection, 15(6), 524-527.

Rosenthal, N. A., LE Lee, Vermeulen, B. A. J., Hedberg, K., Keene, W. E., Widdowson, M. A., et al. (2011). Epidemiological and genetic characteristics of norovirus outbreaks in long-term care facilities, 2003-2006. Epidemiology and Infection, 139(2), 286-294.

Saif, L. J., Bohl, E. H., Theil, K. W., Cross, R. F., \& House, J. A. (1980). Rotavirus-like, calicivirus-like, and 23-nm virus-like particles associated with diarrhea in young pigs. Journal of Clinical Microbiology, 12(1), 105-111.

Sakon, N., Yamazaki, K., Yoda, T., Kanki, M., Otake, T., \& Tsukamoto, T. (2005). A norovirus outbreak of gastroenteritis linked to packed lunches. Japanese Journal of Infectious Diseases, 58(4), 253.

Sala, M. R., Cardenosa, N., Arias, C., Llovet, T., Recasens, A., Dominguez, A., et al. (2005). An outbreak of food poisoning due to a genogroup I norovirus. Epidemiology and Infection, 133(1), 187-191.

Schets, F. M., Van Wijnen, J. H., Schijven, J. F., Schoon, H., \& de Roda Husman, A. M. (2008). Monitoring of waterborne pathogens in surface waters in Amsterdam, The Netherlands, and the potential health risk associated with exposure to Cryptosporidium and Giardia in these waters. Applied and Environmental Microbiology, 74(7), 2069-2078.

Schmid, D., Stuger, H. P., Lederer, I., Pichler, A. M., KainzArnfelser, G., Schreier, E., et al. (2007). A foodborne norovirus outbreak due to manually prepared salad, Austria 2006. Infection, 35(4), 232-239.

Scipioni, A., Mauroy, A., Vinje, J., \& Thiry, E. (2008). Animal noroviruses. The Veterinary Journal, 178(1), 32-45.

Sekla, L., Stackiw, W., Dzogan, S., \& Sargeant, D. (1989). Foodborne gastroenteritis due to Norwalk virus in a Winnipeg hotel. CMAJ: Canadian Medical Association Journal, 140(12), 1461-1464.

Shen, Q., Zhang, W., Yang, S., Chen, Y., Ning, H., Shan, T., et al. (2009). Molecular detection and prevalence of porcine caliciviruses in eastern China from 2008 to 2009. Archives of Virology, 154(10), 1625-1630.

Showell, D., Sundkvist, T., Reacher, M., \& Gray, J. (2007). Norovirus outbreak associated with canteen salad in Suffolk, United Kingdom. Euro Surveillance, 12(11), E071129.6.

Siebenga, J. J., Lemey, P., Pond, S. L. K., Rambaut, A., Vennema, H., \& Koopmans, M. (2010). Phylodynamic reconstruction reveals norovirus GII. 4 epidemic expansions and their molecular determinants. PLoS Pathogens, 6(5), e-1000884.

Siebenga, J. J., Vennema, H., Duizer, E., \& Koopmans, M. P. G. (2007). Gastroenteritis caused by norovirus GGII.4, the Netherlands, 1994-2005. Emerging Infectious Diseases, 13(1), 144-146.

Siebenga, J. J., Vennema, H., Zheng, D. P., Vinje, J., Lee, B. E., Pang, X. L., et al. (2009). Norovirus illness is a global problem: Emergence and spread of norovirus GII.4 variants, 2001-2007. Journal of Infectious Diseases, 200(5), 802-812.

Smiley, J. R., Hoet, A. E., Travén, M., Tsunemitsu, H., \& Saif, L. J. (2003). Reverse transcription-PCR assays for detection of bovine enteric caliciviruses (BEC) and analysis of the genetic relationships among BEC and human caliciviruses. Journal of Clinical Microbiology, 41(7), 3089-3099.

Springthorpe, S., \& Sattar, S. A. (2007). Chapter 6 Virus removal during drinking water treatment. vol. 17, 109-126.

Stals, A., Baert, L., De Keuckelaere, A., Van Coillie, E., \& Uyttendaele, M. (2011a). Evaluation of a norovirus detection methodology for ready-to-eat foods. International Journal of Food Microbiology, 145(2-3), 420-425.

Stals, A., Baert, L., Jasson, V., Van Coillie, E., \& Uyttendaele, M. (2011b). Screening of fruit products for norovirus and the difficulty of interpreting positive PCR results. Journal of Food Protection, 74(3), 425-431.

Stals, A., Baert, L., Van Coillie, E., \& Uyttendaele, M. (2011c). Evaluation of a norovirus detection methodology for soft red fruits. Food Microbiology, 28(1), 52-58.

Steele, M., \& Odumeru, J. (2004). Irrigation water as source of foodborne pathogens on fruit and vegetables. Journal of Food Protection, 67(12), 2839-2849.

Sugieda, M., Nagaoka, H., Kakishima, Y., Ohshita, T., Nakamura, S., \& Nakajima, S. (1998). Detection of Norwalk-like virus genes in the caecum contents of pigs. Archives of Virology, 143(6), $1215-1221$.

Summa, M., von Bonsdorff, C. H., \& Maunula, L. (2012a). Evaluation of four virus recovery methods for detecting noroviruses on fresh lettuce, sliced ham, and frozen raspberries. Journal of Virological Methods, 183(2), 154-160.

Summa, M., von Bonsdorff, C. H., \& Maunula, L. (2012b). Pet dogs, a transmission route for human noroviruses? Journal of Clinical Virology, 53(3), 244-247.

Takanashi, S., Wang, Q., Chen, N., Shen, Q., Jung, K., Zhang, Z., et al. (2011). Characterization of emerging GII. g/GII. 12 noroviruses from a gastroenteritis outbreak in the United States in 2010. Journal of Clinical Microbiology, 49(9), 3234-3244.

Takkinen, J. (2006). Recent norovirus outbreaks on river and seagoing cruise ships in Europe. Euro Surveillance, 11(6), e-060615.2.

Terio, V., Martella, V., Moschidou, P., Di Pinto, P., Tantillo, G., \& Buonavoglia, C. (2010). Norovirus in retail shellfish. Food Microbiology, 27(1), 29-32.

Teunis, P. F. M., Rutjes, S. A., Westrell, T., \& de Roda Husman, A. M. (2009). Characterization of drinking water treatment for virus risk assessment. Water Research, 43(2), 395-404.

Thackray, L. B., Wobus, C. E., Chachu, K. A., Liu, B., Alegre, E. R., Henderson, K. S., et al. (2007). Murine noroviruses comprising a single genogroup exhibit biological diversity despite limited sequence divergence. Journal of Virology, 81(19), 10460-10473.

Todd, E. C. D., Greig, J. D., Bartleson, C. A., \& Michaels, B. S. (2009). Outbreaks where food workers have been implicated in the spread of foodborne disease. Part 6. Transmission and survival of pathogens in the food processing and preparation environment. Journal of Food Protection, 72(1), 202-219.

Ueki, Y., Sano, D., Watanabe, T., Akiyama, K., \& Omura, T. (2005). Norovirus pathway in water environment estimated by genetic 
analysis of strains from patients of gastroenteritis, sewage, treated wastewater, river water and oysters. Water Research, 39(18), 4271-4280.

Ueki, Y., Shoji, M., Suto, A., Tanabe, T., Okimura, Y., Kikuchi, Y., et al. (2007). Persistence of caliciviruses in artificially contaminated oysters during depuration. Applied and Environmental Microbiology, 73(17), 5698-5701.

van den Berg, H., Lodder, W., van der Poel, W., Vennema, H., \& de Roda Husman, A. M. (2005). Genetic diversity of noroviruses in raw and treated sewage water. Research in Microbiology, 156(4), 532-540.

van der Poel, W. H., Van der Heide, H. R., Verschoor, F., Gelderblom, H., Vinje, J., \& Koopmans, M. P. (2003). Epidemiology of Norwalk-like virus infections in cattle in The Netherlands. Veterinary Microbiology, 92(4), 297-309.

van der Poel, W. H., Vinje, J., van Der Heide, R., Herrera, M. I., Vivo, A., \& Koopmans, M. P. (2000). Norwalk-like calicivirus genes in farm animals. Emerging Infectious Diseases, 6(1), 36-41.

Vega, E., Garland, J., \& Pillai, S. D. (2008). Electrostatic forces control nonspecific virus attachment to lettuce. Journal of Food Protection, 71(3), 522-529.

Vega, E., Smith, J., Garland, J., Matos, A., \& Pillai, S. D. (2005). Variability of virus attachment patterns to butterhead lettuce. Journal of Food Protection, 68(10), 2112-2117.

Verhoef, L., Boxman, I. L., Duizer, E., Rutjes, S. A., Vennema, H., Friesema, I. H. M., et al. (2008). Multiple exposures during a norovirus outbreak on a river-cruise sailing through Europe, 2006. Euro Surveillance, 12(1), 246-252.

Verhoef, L. P. B., Kroneman, A., van Duynhoven, Y., Boshuizen, H., van Pelt, W., \& Koopmans, M. (2009). Selection tool for foodborne norovirus outbreaks. Emerging Infectious Diseases, 15(1), 31-38.

Verhoef, L., Vennema, H., van Pelt, W., Lees, D., Boshuizen, H., Henshilwood, K., et al. (2010). Use of norovirus genotype profiles to differentiate origins of foodborne outbreaks. Emerging Infectious Diseases, 16(4), 617-621.

Vinje, J. (2010). A norovirus vaccine on the horizon? The Journal of Infectious Diseases, 202(11), 1623-1625.

Vivancos, R., Shroufi, A., Sillis, M., Aird, H., Gallimore, C. I., Myers, L., et al. (2009). Food-related norovirus outbreak among people attending two barbeques: Epidemiological, virological, and environmental investigation. International Journal of Infectious Diseases, 13(5), 629-635.

Wadl, M., Scherer, K., Nielsen, S., Diedrich, S., Ellerbroek, L., Frank, C., et al. (2010). Food-borne norovirus-outbreak at a military base, Germany, 2009. BMC Infectious Diseases, 10, 30.

Wang, Q. H., Costantini, V., \& Saif, L. J. (2007). Porcine enteric caliciviruses: Genetic and antigenic relatedness to human caliciviruses, diagnosis and epidemiology. Vaccine, 25(30), $5453-5466$.

Wang, Q. H., Han, M. G., Cheetham, S., Souza, M., Funk, J. A., \& Saif, L. J. (2005a). Porcine noroviruses related to human noroviruses. Emerging Infectious Diseases, 11(12), 1874-1881.

Wang, Q. H., Han, M. G., Funk, J. A., Bowman, G., Janies, D. A., \& Saif, L. J. (2005b). Genetic diversity and recombination of porcine sapoviruses. Journal of Clinical Microbiology, 43(12), 5963-5972.

Wang, Q. H., Souza, M., Funk, J. A., Zhang, W., \& Saif, L. J. (2006). Prevalence of noroviruses and sapoviruses in swine of various ages determined by reverse transcription-PCR and microwell hybridization assays. Journal of Clinical Microbiology, 44(6), 2057-2062.

Webby, R. J., Carville, K. S., Kirk, M. D., Greening, G., Ratcliff, R. M., Crerar, S. K., et al. (2007). Internationally distributed frozen oyster meat causing multiple outbreaks of norovirus infection in Australia. Clinical Infectious Diseases, 44(8), 1026-1031.
Wei, J., Jin, Y., Sims, T., \& Kniel, K. E. (2010). Manure-and biosolids-resident murine norovirus 1 attachment to and internalization by Romaine lettuce. Applied and Environmental Microbiology, 76(2), 578-583.

Wei, J., Jin, Y., Sims, T., \& Kniel, K. E. (2011). Internalization of murine norovirus 1 into Lactuca sativa during irrigation. Applied and Environmental Microbiology, 77(7), 2508-2512.

Wei, J., \& Kniel, K. E. (2010). Pre-harvest viral contamination of crops originating from fecal matter. Food and Environmental Virology, 2(4), 195-206.

Westrell, T., Teunis, P., van den Berg, H., Lodder, W., Ketelaars, H., Stenström, T. A., et al. (2006). Short-and long-term variations of norovirus concentrations in the Meuse river during a 2-year study period. Water Research, 40(14), 2613-2620.

White, K., Osterholm, M. T., Mariott, J., Lawrence, D. H., Ristinen, T., \& Greenberg, H. B. (1986). A foodborne outbreak of Norwalk virus gastroenteritis evidence for post-recovery transmission. American Journal of Epidemiology, 124(1), 120-126.

Wick, J. Y. (2012). Norovirus: Noxious in nursing facilities: Almost unavoidable. The Consultant Pharmacist, 27(2), 98-104.

Widdowson, M. A., Rockx, B., Schepp, R., van der Poel, W. H. M., Vinje, J., van Duynhoven, Y. T., et al. (2005a). Detection of serum antibodies to bovine norovirus in veterinarians and the general population in the Netherlands. Journal of Medical Virology, 76(1), 119-128.

Widdowson, M. A., Sulka, A., Bulens, S. N., Beard, R. S., Chaves, S. S., Hammond, R., et al. (2005b). Norovirus and foodborne disease, United States, 1991-2000. Emerging Infectious Diseases, 11(1), 95-102.

Wise, A. G., Monroe, S. S., Hanson, L. E., Grooms, D. L., Sockett, D., \& Maes, R. K. (2004). Molecular characterization of noroviruses detected in diarrheic stools of Michigan and Wisconsin dairy calves: Circulation of two distinct subgroups. Virus Research, 100(2), 165-177.

Wolf, S., Williamson, W., Hewitt, J., Lin, S., Rivera-Aban, M., Ball, A., et al. (2009). Molecular detection of norovirus in sheep and pigs in New Zealand farms. Veterinary Microbiology, 133(1-2), 184-189.

Wolf, S., Williamson, W. M., Hewitt, J., Rivera-Aban, M., Lin, S., Ball, A., et al. (2007). Sensitive multiplex real-time reverse transcription-PCR assay for the detection of human and animal noroviruses in clinical and environmental samples. Applied and Environmental Microbiology, 73(17), 5464-5470.

Woode, G. N., \& Bridger, J. C. (1978). Isolation of small viruses resembling astroviruses and caliciviruses from acute enteritis of calves. Journal of Medical Microbiology, 11(4), 441-452.

World Health Organization (2008). Foodborne disease outbreaks: guidelines for investigation and control.

Yang, Y., Xia, M., Tan, M., Huang, P., Zhong, W., Pang, X. L., et al. (2010). Genetic and phenotypic characterization of GII-4 noroviruses that circulated during 1987 to 2008. Journal of Virology, 84(18), 9595-9607.

Yin, Y., Tohya, Y., Ogawa, Y., Numazawa, D., Kato, K., \& Akashi, H. (2006). Genetic analysis of calicivirus genomes detected in intestinal contents of piglets in Japan. Archives of Virology, 151(9), 1749-1759.

Yoder, J. S., Blackburn, B. G., Craun, G. F., Hill, V., Levy, D. A., Chen, N., et al. (2004). Surveillance for waterborne-disease outbreaks associated with recreational water-United States, 2001-2002. Morbidity and Mortality Weekly Report, 53(8), $1-22$.

Zainazor, C. T., Hidayah, M. S. N., Chai, L. C., Tunung, R., Ghazali, F. M., \& Son, R. (2010). The scenario of norovirus contamination in food and food handlers. Journal of Microbiology and Biotechnology, 20(2), 229-237. 
Zakhour, M., Maalouf, H., Di Bartolo, I., Haugarreau, L., Le Guyader, F. S., Ruvoen-Clouet, N., et al. (2010). Bovine norovirus: Carbohydrate ligand, environmental contamination, and potential cross-species transmission via oysters. Applied and Environmental Microbiology, 76(19), 6404-6411.

Zheng, D. P., Ando, T., Fankhauser, R. L., Beard, R. S., Glass, R. I., \& Monroe, S. S. (2006). Norovirus classification and proposed strain nomenclature. Virology, 346(2), 312-323.
Zheng, D. P., Widdowson, M. A., Glass, R. I., \& Vinje, J. (2009). Molecular epidemiology of GII. 4 noroviruses in the US between 1994 and 2006. Journal of Clinical Microbiology, 48(1), $168-177$.

Zomer, T. P., De Jong, B., Kühlmann-Berenzon, S., Nyrén, O., Svenungsson, B., Hedlund, K. O., et al. (2009). A norovirus outbreak at a manufacturing company. Epidemiology and Infection, 138, 501-506. 